\title{
Molecularbiology of Basal Cell Carcinoma
}

\author{
Eva-Maria Fabricius, Bodo Hoffmeister and Jan-Dirk Raguse \\ Clinic for Oral and Maxillofacial Surgery, Campus Virchow Hospital \\ Charité - Universitätsmedizin Berlin \\ Germany
}

\section{Introduction}

Basal cell carcinoma is the most frequently occurring skin tumor. Most cases are not life threatening. Only a very small proportion of BCCs metastasize. A high tendency to recurrence makes characterizing BCCs and tumor margin areas obligatory. It will assist in better understanding their pathogenesis and in more effective treatment through prevention of recurrence and second primary disease. In addition to histopathological assessment, the spread of the primary tumor according to TNM classification is crucial for estimating the further development of the disease.

\subsection{Molecular alterations involved in the emergence and development of basal cell carcinomas (BCC)}

While it has not been fully clarified which primary cell gives rise to basal cell carcinomas it is supposed that BCCs arise from interfollicular basal cells, keratinous cells of hair follicles or sebaceous glands (1 to 6). Chemically induced BCCs were produced in the pilosebaceous structures of rats $(3,7)$. Solar ultraviolet radiation (UVR), in particular ultraviolet B (UVB, waveband $280-315 \mathrm{~nm}$ ), is a major and significant factor (8 to 23) in many of the carcinogenic steps leading to basal cell carcinomas. Additional risk factors are predisposing syndromes and genetic predisposition (3, 11 to 14, 16, 19, 24 to 41), such as skin-type (13, 42, 43), viral infections, above all human papilloma viruses (HPV) and / or immunosuppression $(3,13$, $17,20,35,39,41,44$ to 46$)$. The influence of UVB is evident from the fact that BCC incidence is lowest in Finland $(47,48)$ and highest in Australia $(13,47$ to 51$)$. Incidence increases with advancing age through the accumulation of UV-radiation $(52,53)$. UVB exposure and chronic oxidative stress (54) effect direct DNA damage, mutations and chromosome aberrations in the skin (41, 55 to 57), all of which are found in basal cell carcinomas. They are comparable with squamous cell carcinomas (58) insofar as field cancerization can be shown in the environment of the BCC (59 to 63). The BCC can be characterized by certain markers such as proof of p53. Figure 1 illustrates UVB damage with regard to the mutation and inactivation of tumor suppressor gene p53 as well as activation of telomerase during cancerization, particularly in basal cell carcinomas (64).

The inactivation of tumor suppressor activity is a universal step in the development of human cancers $(65,66)$. With inactivation p53 looses its function as the "guardian of the genome" (66) thanks to which it normally controls, among other things, the normal cell 
cycle, arresting irregularly growing cells via G1 / G2 transition of the cell cycle and compelling them to programmed suicide, apoptosis (67 to 76). bcl-2 can block and control p53-dependent apoptosis and loss of bcl-2 stimulates apoptosis (67 to 71, 73, 77, 78). While wild-type p53 suppresses cell growth, p53 mutations reduce DNA repair, for example after UVB radiation, and stop apoptosis. That can explain the increased incidence of skin tumors such as basal cell carcinoma through UVB radiation (13, 79 to 82$)$.

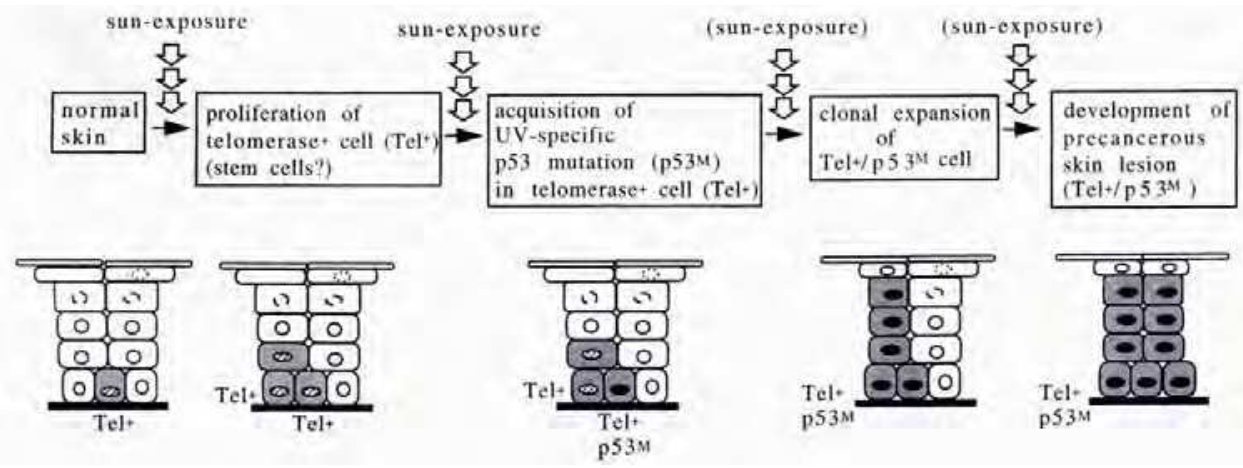

Fig. 1. Carcinogenesis of basal cell carcinomas. Concept for the course of molecular changes in the cancerogenesis of basal cell carcinomas: adapted and reprinted by permission of the American Association for Cancer Research: Ueda et al. (64) (Tel+ = telomerase activation).

\subsection{Molecular markers for differentiation of BCC and SCC of the skin}

Basal cell carcinomas and squamous cell carcinomas of the skin are differentiated by means of histopathological staining, mostly with hemalaun-eosin staining. This can lead to difficulty, as seen for instance in cytology. Vega-Memije et al. (83) introduced Papanicolaou staining to successfully distinguish between the two carcinoma types, and this was also used by Christensen et al. (84) along with May-Grünwald-Giemsa staining for the cytological differentiation of BCCs and actinic keratosis. Tellechea et al. (85) used immunohistochemical anti-Ber-EP4 monoclonal antibody. The total of 22 BCCs showed positive reactions, while in 21 SCCs the reaction was negative, proving this monoclonal antibody suitable for differentiating between the two nonmelanomatous skin-tumors. It was confirmed by Beer et al. (86) who verified expression of Ber-EP4 in all of 39 BCCs and in none of 23 SCCs tested. Swanson et al. (87) were able to distinguish BCCs both from SCCs of the skin and from trichoepitheliomas (TE) with proven expression of Ber-EP4 (also of bcl-2 and CD34): The reaction of Ber-EP4 was positive in all of 44 BCCs, in $81 \%(29 / 36)$ of TEs and in none of 22 SCCs. According to the same procedure, Tope et al. (88) differentiated between BCC, actinic keratosis (AK) and SCCs: All of 5 superficial BCCs were Ber-EP4 positive, while all of 10 AKs and of 8 SCCs were negative. To differentiate between BCCs and SCCs the BerEP4 marker is the most suited. Swanson et al. (87) differentiated with CD34 BCCs, SCCs and TEs: CD34 was positive in 16\% (7/43) of BCCs, in 25\% (5/20) of SCCs and in 8\% (3/36) of TEs. Likewise, Yada et al. (89) and Aiad and Hanout (90) were able to discriminate BCC from SCC immunohistochemically with CD10. In the study by Yada et al. (89) BCCs expressed CD10 1+ to 2+ in 86\% (44/51) and in all 9 SCCs CD10 was negative. According to 
Aiad and Hanout (90) CD10 expression was significantly higher in BCCs than in SCCs: $10 / 21(48 \%)$ and $0 / 16$ SCC $(p=0.002)$.

Guttinger et al. (91), Seelentag et al. (92), Dietrich et al. (93) and Seiter et al. (94) used immunohistochemical methods with monoclonal anti-CD44s and various anti-CD44 splice variant antibodies to differentiate BCCs and SCCs. Guttinger et al. (91) obtained distinct marking of tumor cells (++) in all SCCs with anti-CD44s, CD44v4, CD44v6 and CD44v9 antibodies. The nodular BCCs showed no expression and the sklerodermiform BCCs $(+)$ a weaker expression. This result was congruent with studies by Seelentag et al. (92). Seelentag et al. observed the expression of CD44s, CD44v3, CD44v4, CD44v6 and CD44v9 in immunohistochemical paraffin sections. They (92) achieved higher or distinctly higher expression of CD44v3, CD44v5, CD44v6 and CD44v9 in SCCs of the skin $(n=37)$ than in BCCs $(n=10)$. In BCCs the expression was low (CD44s, CD44v3) or absent (CD44v4). Higher expression in BCCs was found with the splice variants CD44v5, CD44v6 and CD44v9. In squamous cell carcinomas Seelentag et al. (92) found CD44v3, CD44v5, CD44v6 and CD44v9 expression comparable with that in keratoacanthomas $(n=12)$. CD44s and CD44v4 expression was lower in SCCs than in keratoacanthomas. This contradicted the findings by Dietrich et al., (93) who demonstrated CD44v4, CD44v5 and CD44v6 both in BCCs $(n=7)$ and in SCCs $(n=6)$. Indeed, using immunohistochemical methods Dietrich et al (93) demonstrated expression of CD44v7/8 and CD44v10 in all BCCs but in none of the SCCs tested. Forming groups according to the estimated percentage of staining cells, Seiter et al. (94) assessed expression of CD44s, CD44v5, CD44v6, CD44v7, CD44v7/8 and CD44v10 semiquantitatively. In the BCCs and SCCs they investigated, CD44s was expressed in the same degree, while all splice variants tested showed higher expression in SCCs. Simon et al. (95) checked the suitibility of immunohistochemistry for definite distinction between BCCs and SCCs with splice variants CD44v3, CD44v4, CD44v5, CD44v6, CD44v7/8 or CD44v10. All splice variants stained the tumor center of BCCs, while in SCCs only tumor periphery was marked. 12/17 BCCs (71\%) were positive with CD44v3 and 13/17 (77\%) with CD44v5. The remaining CD44-splice variants marked all BCCs, and all of 16 SCCs were marked with all CD44-splice variants. In an immunohistochemical study by Son et al. (96), $49 \%$ of BCCs and only $35 \%$ of SCCs showed CD44v6 marking.

Al-Sader et al. (97) sought to differentiate immunohistochemically the proliferative indices between BCCs and SCCs. The median scores of the mitotic index were 5 for BCCs and 4 for SCCs $(p=0.621)$, but the authors (97) observed that the median scores of Ki-67 were significantly different, amounting to 271 (per 1000 cells) in BCCs and 340 (per 1000 cells) in SCCs $(p=0.029)$. To differentiate BCCs from skin-SCCs, Park et al. (98) used immunohistochemical proof of p53, p63 and survivin. With p53 the authors were unable to differentiate between the two, which were malignant in differing degrees: $90 \% 2+$ to $3+$ vs. $100 \% 2+$ to $3+$. Proof of p63 made this distinction possible: BCC $90 \% 2+$ to $3+$, SCC $40 \% 2+$, as did proof of survivin (BCC $40 \% 2+$, SCC $80 \% 2+$ to $3+$ ). However, Bäckvall et al. (99) succeeded in demonstrating a significant difference between normal skin adjacent to BCC and that adjacent to SCC $(\mathrm{p}<0.05)$ with regard to the number of p53 clones. Chang et al. (100) found significantly less Ki-67 in 10 BCCs investigated (mean score value 12 \pm 7 ) than in 8 SCCs (mean score value $47 \pm 21),(p<0.05)$, and detected clearly different

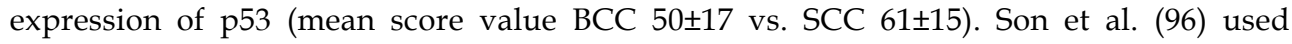


immunohistochemical findings of Ki-67 and p53 to differentiate BCCs $(n=108)$ from SCCs $(n=94)$. Ki-67 expression was low in $90 \%$ of BCCs and high in $10 \%$, while Ki-67 showed high expression in $27 \%$ of SCCs and low expression in $73 \%$. p53 was demonstrated in 15\% of BCCs and in $46 \%$ of SCCs. Bolshakov et al. (101) succeeded in establishing clear differences between aggressive SCCs / nonaggressive SCCs and also aggressive BCCs / nonaggressive BCCs through mutation frequency of p53 with single-strand conformation polymorphism and sequencing: frequency of p53 mutations amounted to $35 \%(28 / 80)$ of aggressive SCCs vs. $50 \%(28 / 56)$ of nonaggressive SCCs as opposed to $66 \%(35 / 50)$ of aggressive BCCs vs. 38\% (37/98) of nonaggressive BCCs. Chang et al. (100) also demonstrated a clear differentiation between BCC and SCC by immunohistochemical bcl2 detection: All of 10 BCCs displayed positive marking that was absent in all of 8 SCCs. In consonance with this, Delehedde et al. (80) found immunohistochemically distinct bcl-2 expression $(+++)$ in 17 BCCs examined, which was missing in all of 14 SCCs $(\mathrm{p}<0.05)$. Likewise, Swanson et al. (87) found positive bcl-2 reaction in 91\% (41/45) of BCCs and in $18 \%(4 / 22)$ of SCCs. Contrary to these results Al-Sader et al. (97) observed no difference between the median scores of the apoptotic index in BCCs (10.5 apoptotic cells / 1000 cells) and in SCCs (10 apoptotic cells / 1000 cells).

In our studies we introduced proof of telomerase activity to differentiate BCCs from SCCs (102 to 104), cf. 2.4.1: the proportion of BCCs with activation of telomerase amounted to $87 \%$ $(26 / 30)$ and was barely higher than in SCCs of the skin with $75 \%(9 / 12)$. This result is in approximate conformity with synoptic references: activation of telomerase in $87 \%(177 / 203)$ of BCCs examined altogether and in $77 \%(58 / 75)$ of SCCs of the skin $(103,104)$. However, our studies demonstrated that the score values of immunohistochemical proof with APAAP (105) of the telomerase subunit hTERT cannot be used to differentiate between BCCs $(n=24)$ and SCCs $(n=7)$ of the skin $(106,107)$ : BCC mean score value 9.4 \pm 4.9 (Ab 1: anti-hTERT antibody Calbiochem, USA, code 582005) and 9.0 \pm 4.0 (Ab 2: anti-hTERT antibody code NCL-hTERT Novocastra, UK, clone 44F12,) vs. SCC mean score value 9.9 $\pm 2.4(\mathrm{Ab} 1)$ and 9.1 \pm 3.8 (Ab 2), cf. 2.4.2.

\section{Molecular markers for basal cell carcinomas and tumor-free margin tissues}

Adequate resection of BCCs is of utmost importance in preventing recurrence (108 to 114). Other authors are therefore searching for markers which discriminate between basal cell carcinoma and histopathologically tumor-free margin. In addition to histopathological assessment, assessing the spread of the primary tumor $(\mathrm{T} 1<2 \mathrm{~cm}, \mathrm{~T} 2 \geq 2 \mathrm{~cm})$ according to the TNM classification (115) is crucial for assessing further development of the disease. The risk of recurrence of each tumor is defined as closely as possible to enable choice and application of the most appropriate clinical procedure $(51,116,117)$. Tumor size is important for prognosis of the disease, as is shown by comparison in Kaplan-Meier curves. With all due precaution given the many censored cases, we ascertain that patients with primary T2 tumors relapse much earlier than those with $\mathrm{T} 1$ tumors (Log-rank $\mathrm{p}=0.003$ ): after $14 \pm 2$ months (T2) vs. $65 \pm 16$ months (T1), Figure 2 .

The classification in nonaggressive basal cell carcinomas and aggressive BCCs is predominantly determined by the clinical course of BCCs and by the tendency to recurrence: nonaggressive nodular, micronodular or superficial BCCs and aggressive infiltrative or 
morphea BCCs (20,81, 118 to 121). Additional markers will help to characterize and are essential for distinctly determining the spread of BCCs (19).

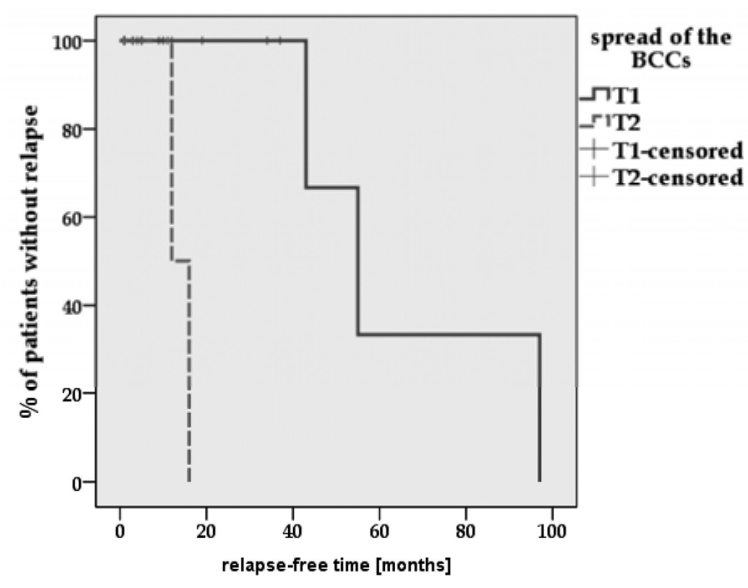

Fig. 2. Up-to-date outcome in patients with BCCs and the spread of the tumor $(\mathrm{T} 1<2 \mathrm{~cm}, \mathrm{~T} 2$ $\geq 2 \mathrm{~cm}$ ) in Kaplan-Meier curves.

\subsection{Different markers classifying nonaggressive and aggressive BCCs}

Staibano and colleagues classified between nonaggressive BCC1 without relapse and aggressive BCC2 with local recurrence during metaphylaxis. For this differentiation they introduced various markers. They detected high expression of p53 in $60 \%$ of 30 BCC2 tumors and low expression in 10\% of BCC1 tumors (122), or in $0 / 21 \mathrm{BCC} 1$ tumors and in $82 \%(18 / 22)$ of BCC2 tumors, respectively (123). Bolshakov et al. (101) were also able to discriminate clearly between aggressive BCCs and nonaggressive BCCs through determination of p53 mutations by single-strand conformation polymorphism and nucleotide sequencing: the frequency of p53 mutations was $66 \%(33 / 55)$ with aggressive BCCs and only 38\% (37/98) with nonaggressive BCCs. In 11 aggressive BCCs Ansarin et al. (121) found significant immunohistochemical nuclear staining of p53 in more than $50 \%$ of tumor cells and in 33 nonaggressive BCCs in less than $50 \%$ of tumor cells $(p<0.01)$.

In BCC1 tumors the AgNOR scores were 6.56 \pm 1.98 and in BCC2-tumors 9.48 \pm 2.12 : De Rosa et al. (119). When Staibano et al. (124) ascertained the apoptotic index, they found a marked difference: BCC1 $5.98 \pm 2.52 \%$ vs. BCC2 $39.82 \pm 8.32 \%$. BCC1 tumors examined showed a distinct cytoplasmic staining of bcl-2. This marker was missing in all of the 30 BCC2 tumors examined by Staibano et al. (122). In agreement with these investigations Ramdial et al. (81) detected a distinctly higher bcl-2 expression in immunohistochemical assays in nonaggressive BCCs than in aggressive BCCs: 45/50 (90\%) nonaggressive BCCs expressed bcl-2 2+ to 4+ and 22/25 (88\%) aggressive BCCs maximally 2+. High expression of cyclin D1 was not found in any BCC1 tumors but in all of 30 BCC2 tumors (125). By determining DNA ploidy Staibano et al. (125) were also able to differentiate between BCC1 and BCC2: All BCC2 tumors were aneuploid as against 77\% of BCC1 tumors. After 
immunohistochemical staining for monoclonal antibody against factor VIII (von Willebrand factor), microscopic counts of microvessels revealed a statistically significant difference: mean score value BCC1 25.76 \pm 2.21 vs. BCC2 46.76 \pm 2.54 (126). Histopathological diagnostics using these markers can be supplementary evidence for the surgeon deciding on the surgical procedure for therapy.

\subsection{Examination of BCC spread by means of anti-CD44 antibodies and anti-splice variant antibodies, by anti-E48 and anti-U36 antibodies}

Cell adhesion molecules such as CD44 splice variants can be used as selective markers for different tumors and are important both for the diagnosis and prognosis of some tumors (127 to 129). Squamous cell carcinomas with poor differentiation display downregulation of CD44v6 expression in comparison with squamous cell carcinomas with high differentiation. Hyckel et al. (130) planimetered the immunohistochemical reaction of oral SCCs by antiCD44 monoclonal antibodies and confirmed an inverse relation to carcinoma grading. Our immunohistochemical findings in frozen sections with APAAP (105) in regard to squamous cell carcinomas of the head-and-neck region (131 to 133) are comparable with the downregulation of isoforms containing CD44v6 that Salmi et al. (134) observed with CD44v3 and CD44v6 in SCCs in the head-and-neck area.

Guttinger et al. (91), Baum et al. (135), Seelentag et al. (92), Seiter et al. (94), Simon et al. (95), Kooy et al. (136), Dingemans et al. $(137,138)$ and Son et al. $(96)$ used immunohistochemical marking on BCCs with CD44v6 and found it better than hemalaun-eosin staining for identifying their local spread. In 20 BCCs, Seelentag et al. (92) found low or no expression of CD44s or CD44v4, contrary to SCCs with low expression of CD44v3. The authors found high expression of CD44v5, CD44v6 and CD44v9 in BCCs, but the expression was lower than in SCCs.

We had previously achieved better results discriminating squamous cell carcinomas of the head and neck from their surroundings with immunohistochemical APAAP (105) in small frozen sections by using adhesion molecules CD44v6 (also its chimera U36) and E48 (131 to 133). This method was now confirmed in BCCs. We accomplished APAAP (105, cf. 131, 132) with a monoclonal antibody against the adhesion molecule CD44v6 (clone VRR-18, Bender, Austria) and with two monoclonal antibodies against adhesion molecules E48 (Centocor B.V., Netherlands) and U36 (Centocor B.V., Netherlands). Antibody E48 has been developed to recognize normal squamous epithelium and squamous cell carcinomas (139). It is well suited for differentiating carcinomas from negative adenocarcinomas and small cell carcinomas (140). Monoclonal anti-U36 antibody is an anti-CD44v6-chimeric (mouse/human) antibody for marking normal human squamous epithelia and squamous cell carcinomas (141 to 143). The quantitative presentation of antigen expression (CD44v6, E48, U36) in frozen sections was evaluated in our study by means of an immunoreactive score (IRS) according to Remmele et al. (144) and Remmele and Stegner (145). Our evaluation was performed three times by an independent examiner. The membrane staining intensities (SI) were divided into 5 levels: negative, 1+ (weak expression) to 5+ (very strong expression). The percentage of positive stained cells (PP) was classified into 4 groups according to percentage of stained cells: $0-<10 \%=$ score $1 ; 10-<50 \%=$ score $2 ; 50$ $<75 \%=$ score $3 ; 75-100 \%=$ score 4 . The IRS was calculated by multiplication of SI and PP. To identifying the spread of BCCs in small frozen sections we applied immunohistochemical 
staining with APAAP (105) to membrane marking of CD44v6, E48 and U36. We found it better than hemalaun-eosin staining.

In our study the immunoreactive scores (IRS) in BCC tumor center vs. tumor-free margin were demonstrated and are illustrated in Figure 3. Only the expression of CD44v6 was significantly higher in tumor center (mean score value 12.5 \pm 3.2 ) than in squamous epithelia in the tumor margin (mean score value $8.4 \pm 4.0, \mathrm{p}=0.006$ ), and was comparable to the expression of Ki-67 ( $\mathrm{p}<0.001)$. Microscopic representation with the three monoclonal antibodies, particularly CD44v6, distinguished BCCs clearly from their surroundings: Figure 4.

The ample expression of CD44v6 and U36 (if necessary E48) adhesion molecules might make them useful both for the diagnostics and adjuvant therapy of BCCs. Radionuclidelabeled purified monoclonal antibodies were successfully developed in VU University Medical Center (Amsterdam/Netherlands). They have proven themselves in this capacity for years in the diagnostics (146 to 152) and therapy $(142,147,153$ to 156) of squamous cell carcinomas in the head-neck-region.

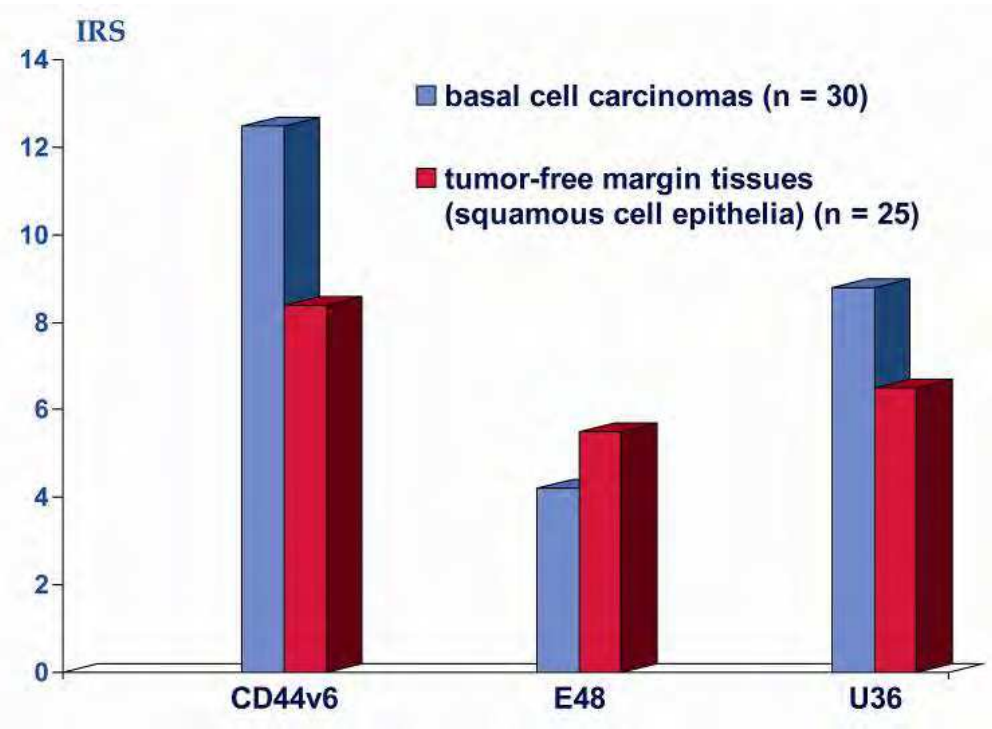

Fig. 3. Immunoreactive scores (IRS, cf. 144, 145) of expression of CD44v6, E48 and U36 in basal cell carcinomas (mean values). 


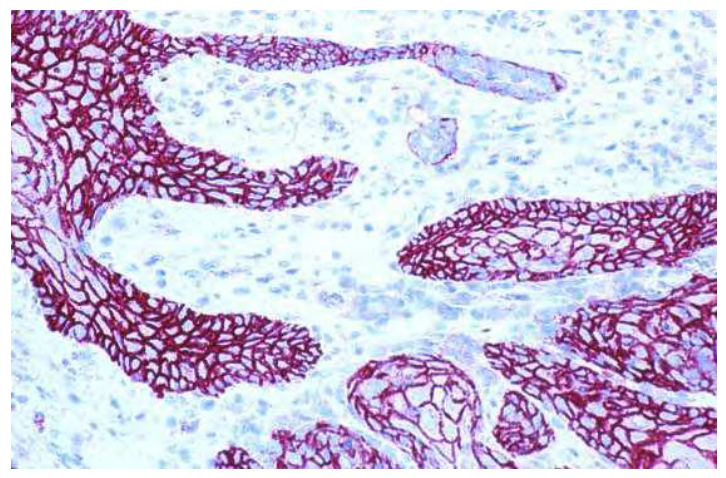

a) CD44v6

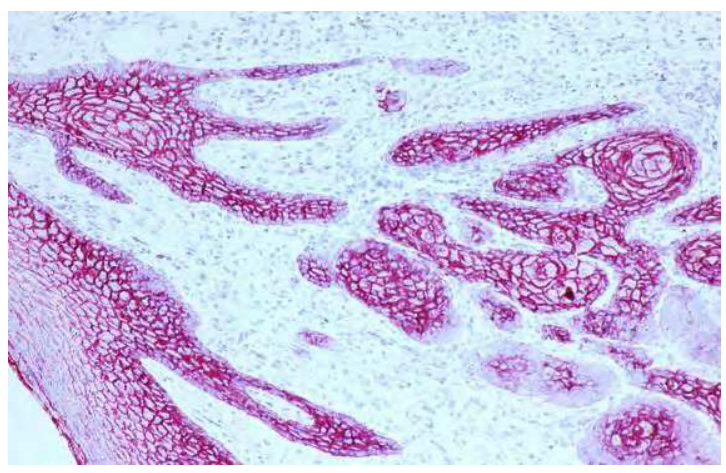

b) $\mathrm{E} 48$

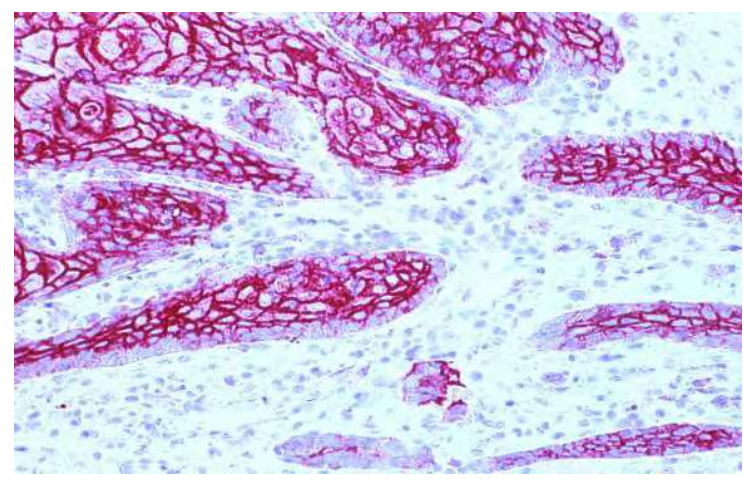

c) U36

Fig. 4. Comparison of expression of CD44v6 (a), E48 (b) and U36 (c) in small frozen sections of BCCs, magnification 200x. 


\subsection{Markers p53 and Ki-67 in BCCs and BCC-free tumor margin tissue}

Molecular alterations can be found during carcinogenesis and tumor growth. As illustrated schematically in Figure 1 (cf. 1.1), the inactivation of tumor suppressor gene p53 is an important step towards carcinogenesis. During inactivation and mutation of p53 mutated p53 protein is formed. Mutated and wildtype p53 protein can be detected immunohistochemically by different or identical antibodies, for instance in tissues with field cancerization after intensive solar irradiation $(60,62)$ as well as in tumor-free margin surrounding of BCCs $(98,157$ to 161). Authors are therefore searching for markers such as p53 which discriminate between basal cell carcinoma and histologically tumor-free margin surrounding the tumor.

\subsubsection{Marker p53 in BCCs and BCC-free tumor margin tissues}

Urano et al. (157) applied immunohistochemistry using anti-p53 antibody clone Do-7, which recognizes both wildtype p53 protein and mutated p53 protein. The authors found significantly lower p53 expression in tumor margin than in tumor center $(p<0.05): 7 / 17$ tissues of tumor margin (41\%) and 11/17 (65\%) of tumor center were p53 positive. Barrett et al. (158) were able to detect p53 in 20/27 (74\%) BCCs. They also investigated adjacent actinic keratosis in the tumor margin of 4 tumors and found increased p53 staining. Demirkan et al. (159) detected significantly less p53 in BCC-free tumor margin than in the tumor center: $26 \%(11 / 42)$ p53 positive tumor-free margins vs. $44 \%(8 / 18)$ tumor center tissues ( $p=0.034$ ), the same was found with monoclonal antibody Do-7 (DAKO/Denmark). According to investigations by Rajabi et al. (160), p53 expression in 96/123 BCC tumor tissues $(82 \%)$ was not significantly higher than in 84/117 tumor-free margin tissues $(78 \%)$, $\mathrm{p}=0.38$. The relatively high $\mathrm{p} 53$ expression of the tumor margin could be related to strong sun exposure of uncovered skin with patients in southern latitudes. Bäckvall et al. (99) and Koseoglu et al. (161) were also unable to find a significantly decreased expression of p53 in adjacent tissues surrounding the BCCs. Koseoglu et al. (161) detected p53 clones in 10/43 tumor center tissues (23\%) and in 9/21 tumor margin tissues (42\%).

In our study we employed an antibody from Oncogene (USA) to ascertain p53 scores in small frozen sections: a monoclonal antibody against mutated p53 Ab-3 (OP 29-1) (103, 106, 107). Before performing the APAAP (105), slides with frozen sections were fixed in methanol and acetone and pretreated in a steamer $\left(95\right.$ to $\left.99^{\circ} \mathrm{C}\right)$. This was non-essential for p53 and Ki-67 but for hTERT and retinoic acid receptors nuclear staining in frozen sections essential $(106,107,162)$. We determined p53 scores as described in 2.2. In quantitative presentation of antigen expression (p53, Ki-67, hTERT and retinoid receptors) by means of an immunoreactive score (IRS) we refer exclusively to the nuclear and / or nucleolar staining. We evaluated staining intensity (SI) and number of positive stained cells (PP) in the BCCs and in squamous cell epithelia of the tumor margin. The IRS was calculated by multiplication of SI and PP. In our immunohistochemical investigations the difference between IRS of p53 in tumor center (mean score value 7.9 \pm 3.4 ) was not significantly higher than in tumor margin (mean score value 5.8 \pm 4.2 ), $p=0.095$ : Figure 5 and illustrated in Figure 6a (tumor center) and Figure 6c (tumor margin), cf. 2.3.2. p53 scores in T2-BCCs (8 primary tumors $\geq 2 \mathrm{~cm}$ ) were not higher than in T1-BCCs (17 primary tumors $<2 \mathrm{~cm}$ ): mean score value $6.3 \pm 4.3$ (T2) vs. $7.9 \pm 3.3$ (T1), p=0.328. We tested the role of $\mathrm{p} 53$ scores investigated for prognosis in Kaplan-Meier curves (cf. 2.3.2). We divided all p53 scores (also Ki-67 scores and 
hTERT scores) into two groups (group 1: scores < mean value, group 2: scores $\geq$ mean value) and used the patients' up-to-date outcome as documented in our hospital. With all due reservation due to the many censored cases, we ascertain that BCCs of patients with higher p53 scores in tumor center tissues recurred later, almost significantly later, than BCCs of patients with lower scores in tumor center tissues ( $65 \pm 16$ months vs. $23 \pm 6$ months): Log-rank $\mathrm{p}=0.059$, Figure 7a. However, patients with higher p53 scores in BCC tumor margin tissues did not relapse significantly but nevertheless earlier than patients with lower p53 scores in tumor margin tissues ( $36 \pm 6$ months vs. $40 \pm 11$ months): Log-rank $\mathrm{p}=0.622$, Figure $7 \mathrm{c}$.

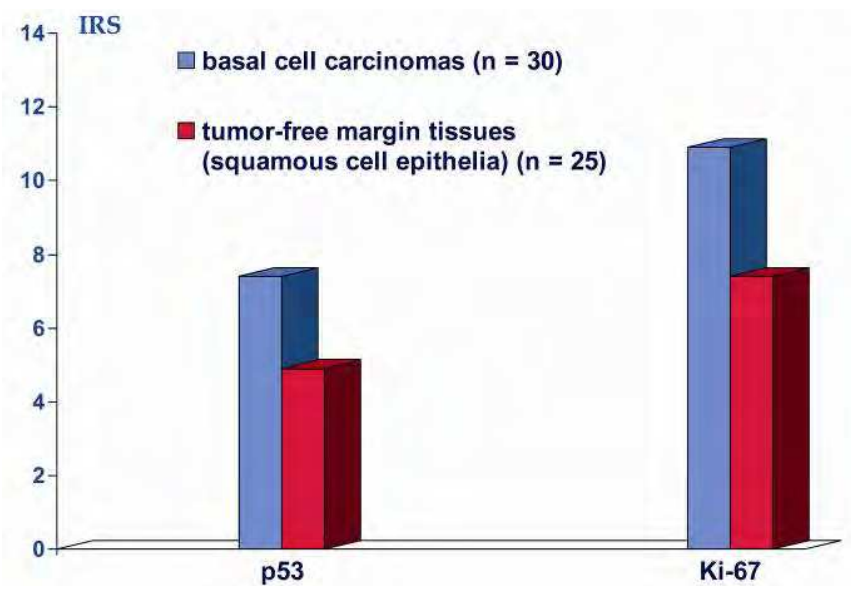

Fig. 5. IRS (immunoreactive scores, cf. 144, 145) mean values of expression of mutated p53 and of Ki-67 in basal cell carcinomas.

\subsubsection{Marker Ki-67 in BCCs and BCC-free tumor margin tissues in comparison with p53}

Some authors compared proof of p53 with expression of the proliferation marker Ki-67. Healy et al. (163) proved 71 BCC tissues immunohistochemically with p53 and Ki-67, 17 BCCs group 1 (patients without recurrence), 17 BCCs group 2-0 (patients who relapsed some time later) and $17 \mathrm{BCC}$ relapses (group 2-R). p53 was demonstrated in 95\% of each group. However, the authors (163) revealed significantly lower values of Ki-67 expression in BCCs in group 1 (mean value 12\%) than in group 2-0 (mean value $25 \%$ ) or group 2-R (mean value 22.5\%): $\mathrm{p}=0.009$. Barrett et al. (158) examined expression of p53, Ki-67 and PCNA in 27 basal cell carcinomas and compared them to histopathological BCC types. Expression of p53 and PCNA was higher in aggressive BCCs than in nonaggressive BCCs, and PCNA was higher than Ki-67. Chang et al. (100) tested 10 BCCs and detected both p53 and Ki-67 in all of them. The labeling index with Ki-67 was significantly lower than with p53: $12 \pm 7$ vs. $50 \pm 17$ $(\mathrm{p}<0.05)$. By contrast, in 20 BCCs Abdelsayed et al. (164) demonstrated higher marking with Ki-67 (mean value 51.25 \pm 6.06 ) and PCNA (mean value 52.25 \pm 7.57 ) than with p53 (mean value 31.75 \pm 9.02 ). Koseoglu et al. (161) also investigated the p53 level of 50 BCCs immunohistochemically in comparison with Ki-67 expression (anti-Ki-67 antibody clone Ki88). They found significantly higher Ki-67 expression in p53 positive tissues (Ki-67 mean value 14.66) than in p53 negative tissues (Ki-67 mean value 8.37): $\mathrm{p}=0.019$. 
a) tumor center tissue of a nodular basal cell carcinoma: expression of mutated $\mathrm{p} 53$

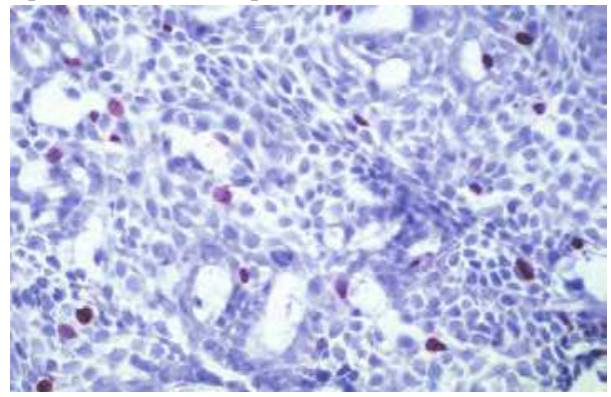

c) tumor-free margin tissue: expression of mutated p53

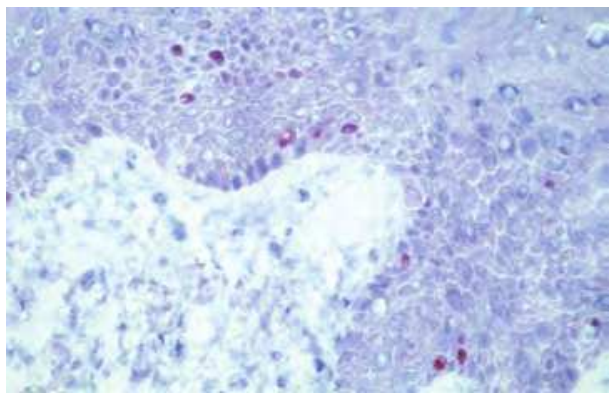

b) tumor center tissue of a nodular basal cell carcinoma: expression of $\mathrm{Ki}-67$

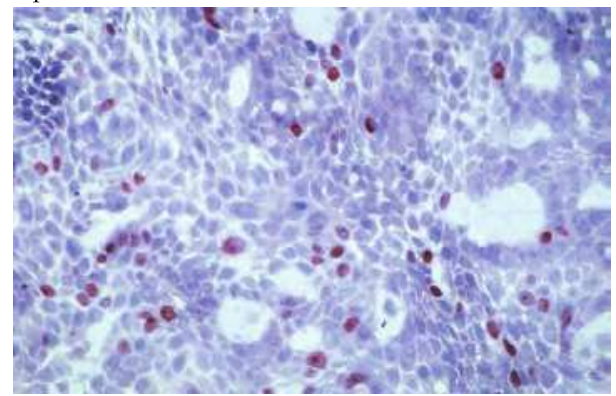

d) tumor-free margin tissue: expression of Ki-67

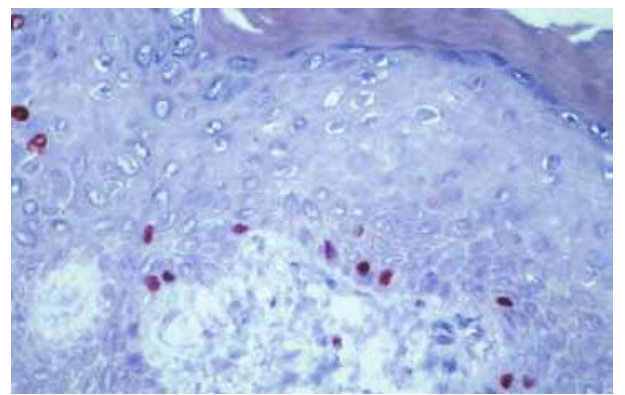

Fig. 6. Comparison of expression of p53 (a, c) and Ki-67 (b, d) in small frozen sections of BCCs $(a, b)$ and in tumor margin tissues $(c, d)$, magnification $400 x$.

We also compared Ki-67 scores with p53 scores in tumor center tissues and tumor-free margin tissues. To prove Ki-67 in small frozen sections we used a monoclonal mouse antihuman Ki-67 antibody (clone MIB-1) from DAKO (Denmark) $(106,107)$. As described under 2.2 and 2.3.1, nuclear staining scores were achieved with immunohistochemical APAAP (105). The Ki-67 mean score value in tumor center (10.9 \pm 2.5$)$ was significantly higher than that in tumor margin (7.4 \pm 1.8$), \mathrm{p}<0.05$ : Figure 5, cf. 2.3.1. Our results with p53 and Ki-67 expression of tumor center and tumor margin tissues are displayed in Figure 6.

We tested the prognostic prediction of Ki-67 status (107) detected in our patients' tissues with BCCs in Kaplan-Meier curves. With all due reservation in view of the number of censored cases, patients with higher Ki-67 scores in tumor center tissues suffered BCC recurrence (not significantly) later (Log-rank $\mathrm{p}=0.560$ ) than patients with lower Ki-67 scores (56 \pm 16 months, higher scores, vs. $27 \pm 7$ months, lower scores): Figure $7 \mathrm{~b}$. In contrast, patients with higher Ki-67-scores in tumor margin tissues did not relapse significantly earlier (Logrank $\mathrm{p}=0.321$ ) than patients with lower Ki-67-scores ( $35 \pm 5$ months, higher scores, vs. $48 \pm 13$ months, lower scores): Figure 7d. 

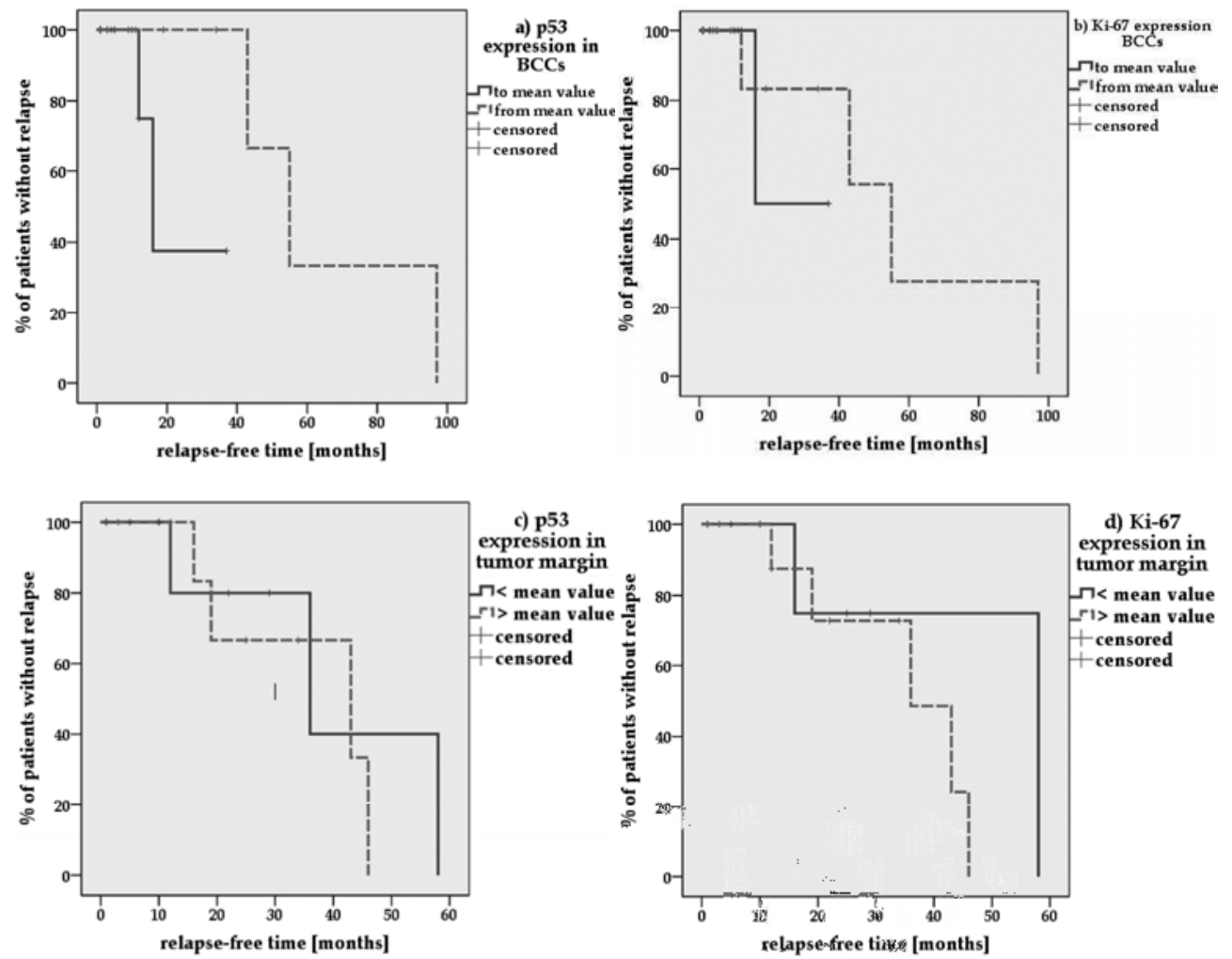

Fig. 7. Kaplan-Meier curves for p53 expression (a, c) and Ki-67 expression (b, d) in BCC tumor center tissues $(a, b)$ and in tumor margin tissues $(c, d)$.

\subsection{The biology of telomerase}

In 1984 Blackburn and Greider discovered telomerase in a single-celled ciliate Tetrahymena $(165,166)$, a ribonucleoprotein enzyme. The enzyme is of universal importance for cell proliferation. Telomerase replaces the mitotic loss of telomeres at chromosome ends with telomeric substitutes. This abrogates the limited cell division potential (the Hayflick limit). Hayflick and Moorhead (167) observed limited cell division in fibroblast cultures. Activation of telomerase occurs during embryogenesis $(168,169)$. In normal somatic tissues with a limited replicative potential telomerase activity can be demonstrated only in traces or not at all (170 to 172). Activation of telomerase can be found inside cells with proliferative potential such as stem cells, in strongly regenerative cells, and in dermal cells of hair follicles $(169,171$ to 175$)$. Telomerase can be activated by UVB in seriously sun-exposed skin $(10,64)$. It may also be detected in benign proliferative lesions (174) or after activation in cells of inflammatory reactions $(170,172,174,176$ to 178). Reactivation of telomerase also occurs in carcinogenesis $(179,180)$, as was illustrated by Ueda et al. (64) (Figure 1, 1.1). It is an essential step for cancer immortalization and cancer progression $(172,180)$. 
However not until Kim et al. (168) developed the polymerase chain reaction based telomeric repeat amplification protocol in 1994 (TRAP assay) was it possible to detect telomerase in greater numbers in unfixed tissues. Since then, a great number of tissues, particularly from cancer, have been investigated for telomerase activity as the reviews by Shay and Bacchetti (181) and Dhaene et al. (182) demonstrate.

\subsubsection{Activation of telomerase in tumor center and tumor margin tissues of BCCs}

The results of telomerase activity in BCCs and tumor-free adjacent tissues have been summarized. The portion of 203 specimens with evidence of telomerase detected with the TRAP assay (168) amounted to an average of $87 \%$, varying between 20 and $100 \%(64,103$, 104,183 to 189). Table 1 sums up telomerase activity of BCCs and tumor-free adjacent tissues. To discriminate between BCC center tissue and tumor-free margin tissue Taylor et al. (183) and Ueda et al. (64) introduced proof of telomerase activity. They found clearly less telomerase activity in tumor margin tissue than in the tumor center: BCC margin tissues with $67 \%$ and $39 \%$ vs. $95 \%$ and $85 \%$ of BCC center tissues.

\begin{tabular}{lll} 
References & $\begin{array}{l}\text { telomerase } \\
\text { positive } \\
\text { in tumor } \\
\text { center tissues }\end{array}$ & $\begin{array}{l}\text { telomerase } \\
\text { positive } \\
\text { in tumor mar } \\
\text { tissues }\end{array}$ \\
\hline ----------------------------------------' & & \\
Taylor et al., 1996 (183) & $73 / 77(95 \%)$ & $38 / 57(67 \%)$ \\
Ueda et al., 1997 (64) & $11 / 13(85 \%)$ & $11 / 28(39 \%)$ \\
Parris et al., $1999(184)$ & $10 / 13(77 \%)$ & \\
Wu et al., 1999 (185) & $10 / 11(91 \%)$ & \\
Kim et al., 2000 (186) & $1 / 5(20 \%)$ & \\
Chen et al., 2001 (187) & $22 / 22(100 \%)$ & \\
Boldrini et al., 2003 (188) & $15 / 20(75 \%)$ & \\
Fabricius et al.,2003 (103) & & \\
and 2006 (104) & $26 / 30(87 \%)$ & $9 / 25(36 \%)$ \\
Saleh et al., 2007 (189) & & \\
& $9 / 12(75 \%)$ & \\
altogether & $\mathbf{1 7 7 / 2 0 3 ( 8 7 \% )}$ & $\mathbf{5 8 / 1 1 0 ( 5 3 \% )}$
\end{tabular}
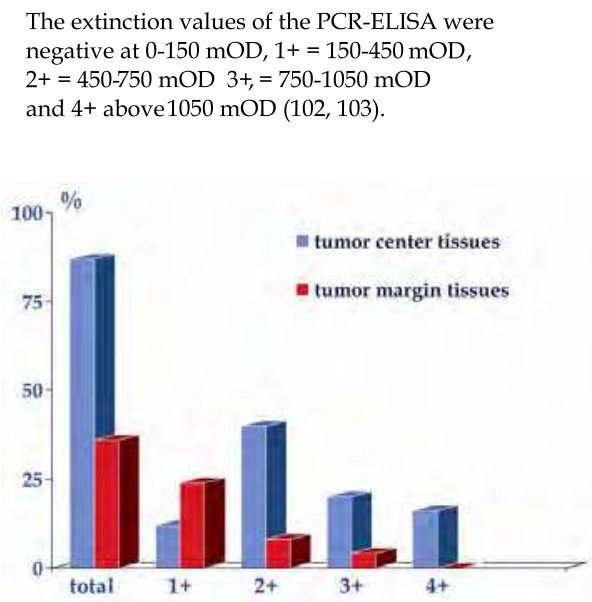

Fig. 8. Telomerase activity in BCCs and in tumor-free margin tissues $(103,104)$

Table 1. The frequency of telomerase activity (detected with the TRAP assay) in basal cell carcinomas and their tumor-free margin tissues.

Like Taylor et al. (183) and Ueda et al. (64), we found significantly higher telomerase activity in $26 / 30(87 \%)$ of BCC tumor center tissues (mean value $661 \pm 388 \mathrm{mOD}$ ) than in $9 / 25(36 \%)$ histopathologically tumor-free tumor margin tissues (mean value $187 \pm 233 \mathrm{mOD})(103,104)$. As we proved telomerase activity semiquantitatively with a PCR-ELISA (Telo TAGGG Telomerase PCR and PCR-ELISA plus, Roche Diagnostics, Germany) we were able to be somewhat more precise: the mean value of telomerase activation in BCC tumor tissues was significantly higher than in tumor margin tissues: $\mathrm{p}<0.001$. In contrast, telomerase activation 
in T2 tumors (mean value $564 \pm 225 \mathrm{mOD}$ ) did not differ significantly from telomerase activation in T1 tumors (mean value $709 \pm 446 \mathrm{mOD}$ ): $\mathrm{p}=0.783$. In Figure 8 , our study on telomerase activation in tumor center and tumor margin has been compiled according to extinction values.

We tested whether the telomerase examined in BCCs or tumor margin tissues has prognostic relevance $(103,104)$. We divided all measured values of telomerase (PCR-ELISA) and divided the patients into two groups, group 1: < mean value and group 2: $\geq$ mean value, and used the patients' up-to-date outcome as documented in our hospital. In Kaplan-Meier curves of tumors and tumor margin tissues, patients with higher telomerase activity suffered recurrence earlier than patients with lower telomerase activity but not significantly: tumor center: $36 \pm 9$ vs. $97 \pm 0$ months (Log-rank: $p=0.100$ ), tumor margin: $19 \pm 1$ vs. $42 \pm 6$ months (Log-rank: p=0.141): Figure 9.
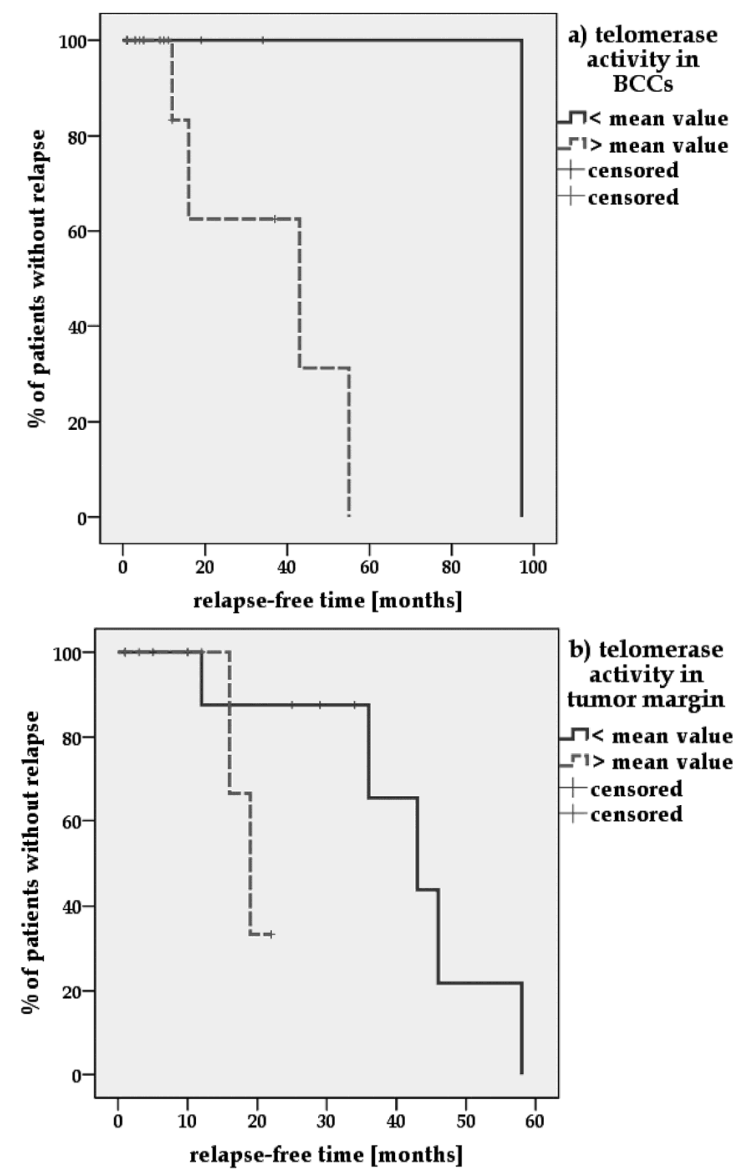

Fig. 9. Comparison of Kaplan-Meier curve for telomerase activity in BCCs (a) and tumor-free margin tissues (b). 
Detection of telomerase activity in unfixed BCC tissues and tumor margin tissues can corroborate, with due reservation in view of the censored cases, histopathological and clinical assessment of risk of recurrence.

\subsubsection{Expression of hTERT in tumor center and tumor margin tissues of BCCs}

hTERT (human telomerase reverse transcriptase) is a catalytic subunit and a component of telomerase $(171,190,191)$. Proof of hTERT protein can be carried out both in unfixed and in fixed tissue and facilitates the localization of telomerase activity. The detectable evidence of the hTERT protein or hTERT mRNA might, however, not always mirror detectable telomerase activity (171).

Saleh et al. (189) used proof of hTERT to differentiate between BCCs of differing size and histopathological type. They determined hTERT in all of 12 BCCs, with no significant difference between mRNA hTERT by RTq-PCR in BCCs of different size: mean value BCCs $<9 \mathrm{~mm} 0.458$ vs. mean value BCCs $\geq 9 \mathrm{~mm} 0.478$. In tumor-free margin tissues of larger BCCs the authors (189) found a somewhat lower, non-significant expression of hTERT mRNA (BCC $<9 \mathrm{~mm}$ mean value 0.160, BCC $\geq 9 \mathrm{~mm} 0.119$ ). hTERT expression of superficial BCCs $(n=5)$, however, was significantly lower $(p<0.05)$ than that of nodular BCCs $(n=7)$ : tumor center mean value 0.305 vs. 0.525 and tumor-free margin 0.094 vs. 0.172 . With senior patients ( $\geq 65$ years of age, $n=6$ ) Saleh et al. (189) succeeded in determining non-significant hTERT expression in tumors and tumor-free margin tissues that was lower than that in younger patients (<65 years of age, $n=6)$ : tumor center mean value 0.343 vs. 0.593 and tumor margin 0.104 vs. 0.175. Proof of hTERT was also established by Hu et al. (192) and Park et al. (98) for evaluating BCCs. Hu et al. (192) examined 62 fresh skin tissues in RT-PCR. They compared hTERT with TPI (another protein component of telomerase) and with hTR, an RNA component of telomerase (171). Part of their study (192) was the investigation of 4 BCCs, all of which expressed hTERT, TPI and 3 / 4 hTR. Park et al. (98) demonstrated hTERT 2+ to 3+ in 8 / 10 BCCs in paraffin sections with anti-hTERT antibody from Calbiochem (USA, Ab-2). Ogoshi et al. (193) used in situ hybridization to prove hTERT and confirmed its occurrence in $93 \%(14 / 15)$ of BCCs.

Attia et al. (194) introduced the anti-hTERT antibody code NCL-hTERT (clone 44F12, Novocastra, UK) for evidence of immunohistochemical hTERT in normal tissues such as in photo-exposed skin. The authors succeeded in proving hTERT $(1+$ to $3+)$ in $80 \%$ of the epidermis of photo-aged subjects. hTERT was expressed in normal skin in the basal layer and in some supra-basal layers, as well as in hair follicles (cf. telomerase activity in hair follicles: 173 to 175$)$.

In our study with small frozen sections we used eleven anti-hTERT antibodies to detect and localize hTERT expression in 25 BCC tumor tissues and 25 tumor margin tissues (107). Previously we had employed the same antibodies to examine squamous cell carcinomas and SCC tumor margin tissues (106). Before performing APAAP (105), slides were fixed in methanol and acetone and pretreated in a steamer $\left(95\right.$ to $\left.99^{\circ} \mathrm{C}\right)$. As described in detail in our first study (106), this pretreatment was essential for hTERT nuclear staining in frozen sections. The most prominent immunohistochemical effects were achieved with anti-hTERT antibody code NCL-hTERT (clone 44F12, Novocastra, UK), 
which was also used by Attia et al. (194) for hTERT detection in sun exposed skin. This antibody was classified later in the paper by $\mathrm{Wu}$ et al. (195) as an antibody against nucleolin. We expanded our investigation and incorporated an anti-nucleolin antibody to clarify this issue $(106,107)$. On the basis of our peptide absorption studies (106) and in agreement with many authors we think that this antibody clone 44F12 Novocastra identifies hTERT. We compared the results of BCCs (107) with antibody Calbiochem, USA, code 582005 and others, and determined the hTERT scores as described in 2.2 and 2.3.1. In the quantitative presentation of antigen expression we refer exclusively to the nuclear and / or nucleolar staining. We evaluated staining intensity (SI) and the number of positive stained cells (PP) in the BCCs and in squamous cell epithelia of the tumor margin. The IRS was calculated by multiplication of SI and PP $(144,145)$.

Our immunohistochemical proof of hTERT is predominantly localized in tumor and in squamous cell epithelia of BCCs and BCC tumor-free margin tissues. hTERT scores with a polyclonal antibody (Calbiochem/USA, code 582005, Ab 1) and with a monoclonal antibody (Novocastra/UK, code NCL-hTERT, clone 44F12, Ab 2) are significantly lower in the tumor margin (mean score values $\mathrm{Ab} 15.4 \pm 3.3$ and $\mathrm{Ab} 2$ 7.0 1 2.9) than in tumor center (mean score

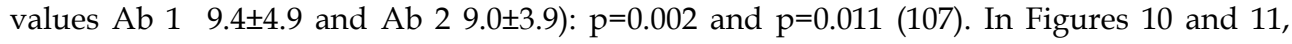
hTERT expression is demonstrated with two antibodies. Proof of hTERT expression now and then differs from telomerase activity.

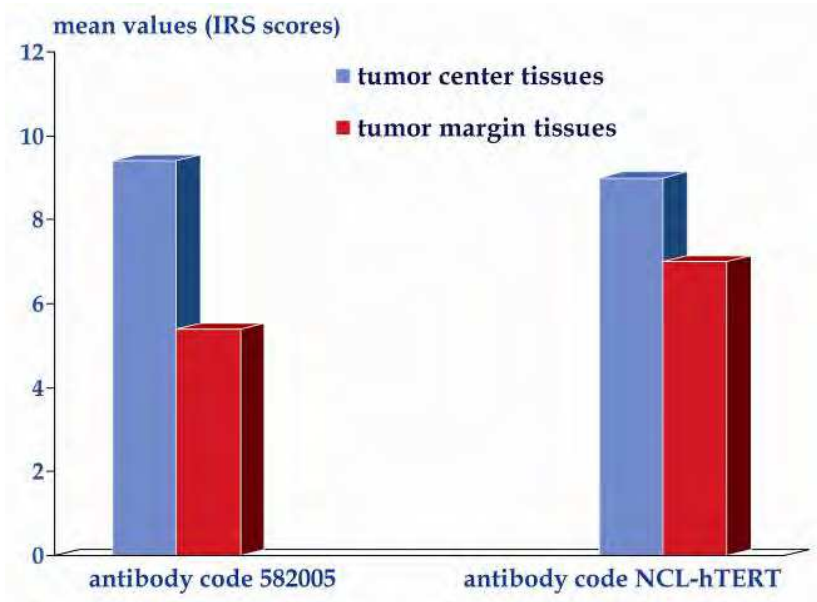

Fig. 10. Mean values of immunoreactive score (cf. 144, 145) with two anti-hTERT antibodies (Calbiochem/USA and Novocastra/UK). 
a) tumor center tissue of a nodular basal cell carcinoma (telomerase activity $3+$ ), $\mathrm{Ab} 1$

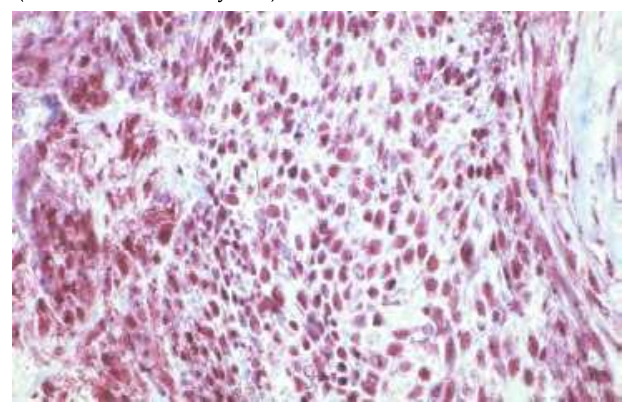

C) tumor center tissue of a mixed nodular-sclerodermiform BCC (telomerase activity $1+$ ), Ab 1

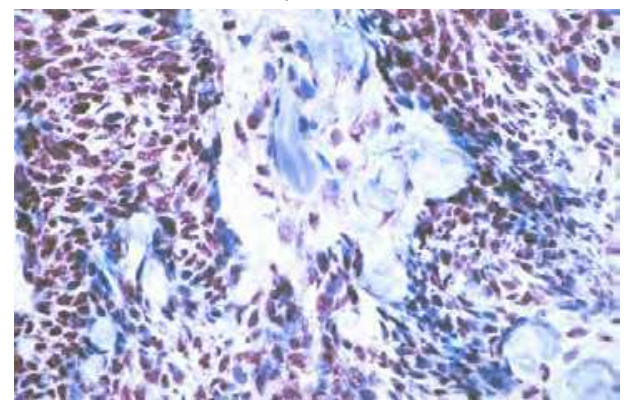

e) tumor margin tissue of a nodular BCC (telomerase activity $1+), \mathrm{Ab} 1$

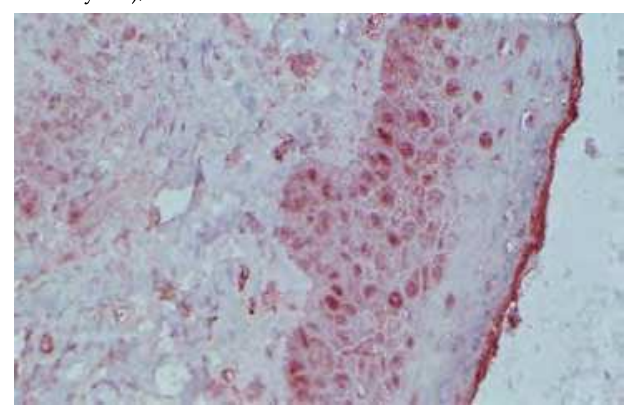

b) tumor center tissue of a nodular basal cell carcinoma (telomerase activity $3+$ ), $\mathrm{Ab} 2$

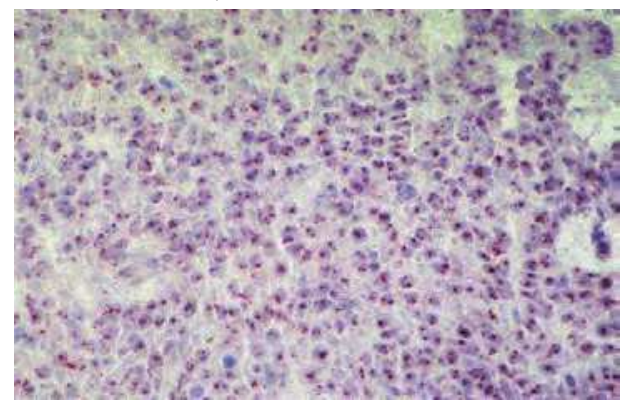

d) tumor center tissue of a mixed nodular-sclerodermiform BCC (telomerase activity 1+), Ab 2

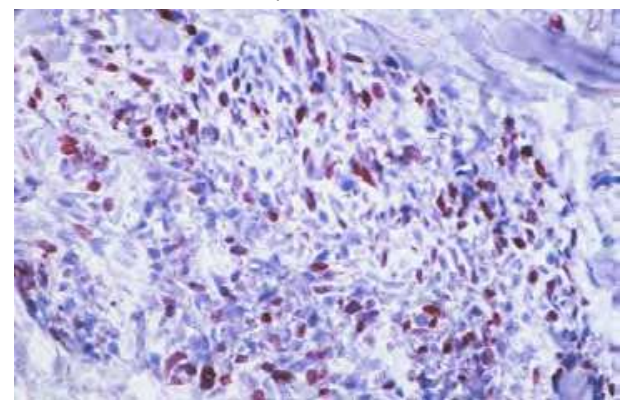

f) tumor margin tissue of a nodular BCC (telomerase activity $1+), \mathrm{Ab} 2$

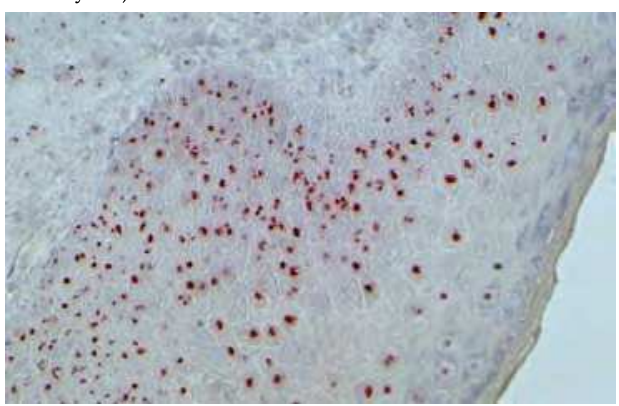

Fig. 11. Comparison of hTERT expression with two anti-hTERT antibodies: polyclonal antibody code 582005, Ab 1 ( $\mathrm{a}, \mathrm{c}$ and e) and monoclonal antibody code NCL-hTERT, clone 44F12, Ab 2 (b, d and f), magnification 400x.

Kaplan-Meier curves indicate that proof of hTERT does not reveal the further course of the disease. We divided all hTERT scores into two groups (group 1: < mean value, group 2: $\geq$ mean value) and related them with the patients' up-to-date outcome as documented in our hospital. With the caveat that there were many censored cases, it can be said that patients with higher hTERT scores in tumor center tissues relapsed earlier than patients with lower hTERT scores in tumor center tissues: antibody code 582005 (Ab 1): $43 \pm 8$ months vs. $70 \pm 31$ months, Log-rank p=0.539, Figure 12a; antibody code NCL-hTERT (Ab 2): $42 \pm 9$ months vs. 
$77 \pm 25$ months, Log-rank $\mathrm{p}=0.387$, Figure $12 \mathrm{~b}$. However, patients with higher hTERT scores in BCC tumor-free margin tissues did not relapse earlier than those with lower hTERT scores in tumor-free margin tissues: antibody code 582005 (Ab 1): $43 \pm 9$ months vs. 30 \pm 9 months, Log-rank p=0.230, Figure 12c; antibody code NCL-hTERT (Ab 2): $39 \pm 5$ months vs. $32 \pm 5$ months, Log-rank $\mathrm{p}=0.686$, Figure $12 \mathrm{~d}$.
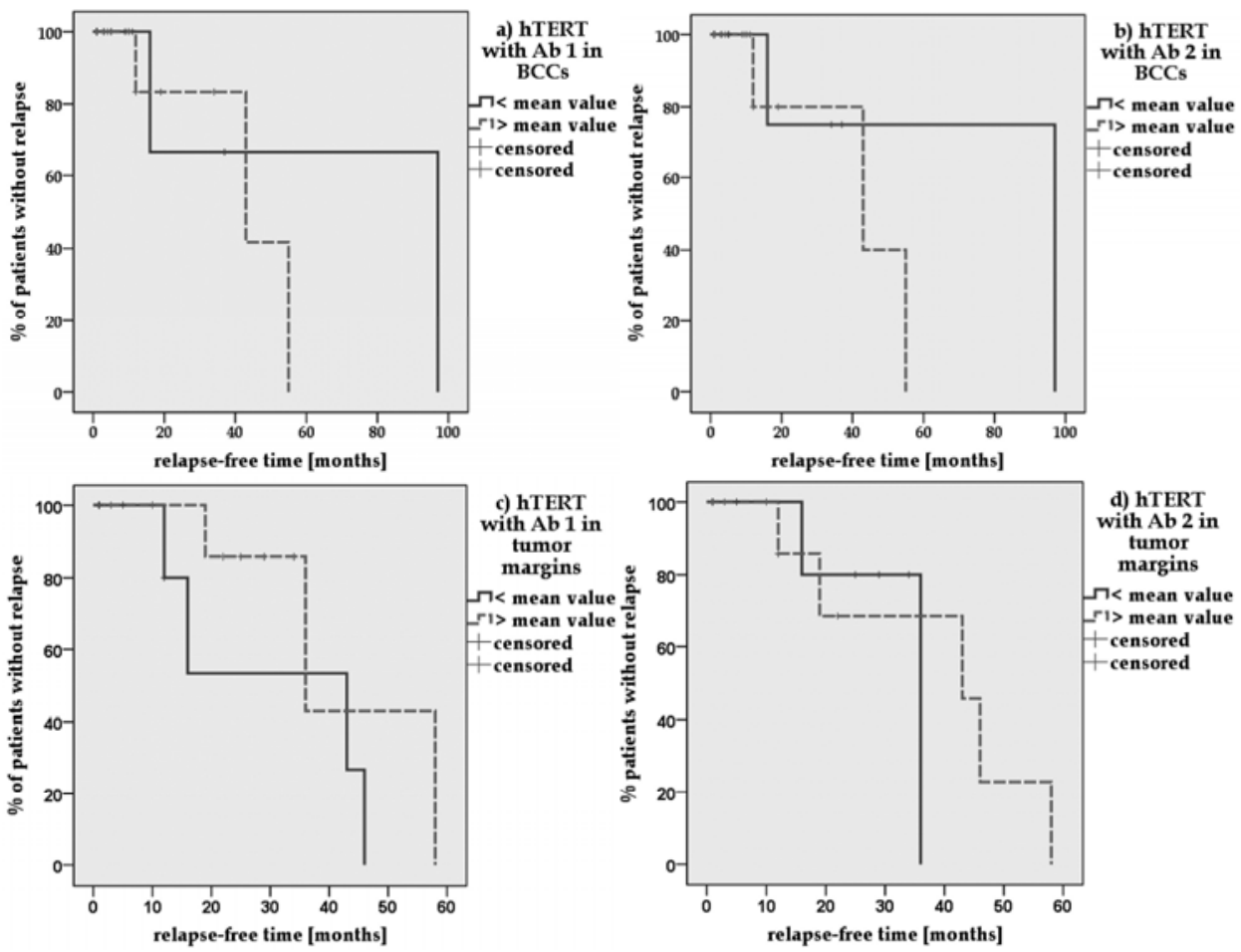

Fig. 12. Kaplan-Meier curves of hTERT expression in BCCs ( $a$ and $b$ ) and tumor-free margin tissues (c and d): Ab 1 = polyclonal antibody code 582005, Ab $2=$ monoclonal antibody code NCL-hTERT.

Our hTERT results in tissues from patients with basal cell carcinoma (107) verify the value of hTERT in localizing the cells in which telomerase is activated (2.4.1). Although we identified differences between eleven antibodies $(106,107)$, we succeeded in detecting hTERT expression primarily in tumor cells and in squamous epithelia cells (Figure 11) after pretreatment of frozen sections in the steamer. We applied the same unfixed tissues for proof of telomerase activity and for hTERT expression. As McKenzie et al. (171) had already discovered, our detection of hTERT might not always mirror detectable telomerase activity (Figure 11, a to f). Kyo et al. (196) arrived at the same conclusion that hTERT did not always correlate with telomerase activity of the various cell types.

Given our previous observations, we decided to evaluate only nuclear or nucleolar expression of hTERT although some antibodies also displayed cytoplasmic staining (106, 107). It must be mentioned, however, that investigations of gynaecologic carcinomatous tissues by Kyo et al. (196) established proof of both hTERT and high levels of telomerase 
after the isolation of cytoplasms, so further evaluation for immunohistochemical proof of hTERT is warranted. Taken together, both telomerase and hTERT may be useful as biomarkers in predicting chemotherapeutic effects (197).

\section{Biomarkers for chemoprevention of basal cell carcinomas}

Given frequent BCC recurrence and field cancerization in tumor-free margin tissues, several studies were launched to investigate the efficacy of chemoprevention in patients with a basal cell carcinoma. The best and primary prevention of basal cell carcinomas is reduction of the most important risk factor, exposure to strong sunlight from childhood $(11,12,15,18$, $21,23,39,52,198)$. The use of agents that inhibit the noxious influence of UV light (199) could therefore be the most effective preventive method. In addition, there have been many studies applying retinoids (topical and oral / systemic) to suppress the emergence of basal cell carcinomas (200 to 207) and thus influence field cancerization of skin and tumor surroundings (59 to 63) to prevent new tumors and / or tumor recurrences. For immunosuppressed patients, chemoprevention is particularly important $(63,198,208$ to 210). After chemoprevention proved to be unsuccessful in most studies, receptor-selective retinoids such as tazarotene were tried out (211 to 218). Tazarotene is selective for retinoic acid receptors RAR $\beta$ and RAR $\gamma$. Thus Bianchi et al. (217) successfully applied tazarotene-gel preoperatively for small superficial and nodular BCCs. This was not successful on keratotic BCCs with high p53 expression, and they were operated afterwards. Crucial for effective retinoic acid chemoprevention and / or therapy is the expression of RAR- and RXRreceptors $(218,219)$, as was demonstrated by So et al. $(220)$. So et al. consider tazarotene to be the most appropriate agent to date for chemoprevention of BCCs.

In addition to synthesis of suitable agents it is essential to search for suitable biomarkers to improve prevention (19), and markers such as p53, Ki-67 or telomerase (2.3 and 2.4) merit consideration along with other genetic markers. Intermediate markers are needed in particular for chemoprevention trials (204). To determine a preliminary endpoint, genetic, cellular, biochemical and immunological surrogate biomarkers - surrogate endpoint markers (SEBs) are being used and validated so that BCC chemoprevention can be evaluated before a recurrence becomes evident (204, 221 to 225). Orlandi et al. (225) employed the markers Ki-67, p53, apoptosis-index, RAR $\alpha, \operatorname{RAR} \beta$ and RAR $\gamma$ before and after tazarotene therapy of 30 BCCs. Expression of Ki-67 was significantly reduced after therapy compared with controls (11\% vs. $29 \%, \mathrm{p}<0.001)$. Expression of p53 was unchanged after therapy. In comparison with controls, however, evidence of apoptotic cells was significantly higher after therapy $(4.5 \%$ vs. $1 \%$, $\mathrm{p}<0.001)$. While expression of RAR $\alpha$ and RAR $\gamma$ was not changed through therapy, expression of receptor RAR $\beta$ was distinctly higher. In our model investigations with cell cultures of oral squamous cell carcinomas, telomerase proved to be a suitable biomarker before and after retinoid therapy (162). Verification with BCCs is yet to follow.

Examination of RAR receptors (retinoic acid receptors) and RXR receptors (retinoid $X$ receptors) on BCCs might indicate why most studies do not show any differences between therapy and placebo groups. Using immunohistochemical methods, Kamradt and Reichrath (226) investigated expression of RAR receptors in frozen sections of 15 basal cell carcinomas: $\operatorname{RAR} \alpha$ was most evident $(3+), \operatorname{RAR} \gamma$ a little weaker $(2+)$ and RAR $\beta$ scanty $(0$ to $1+)$. This corroborates studies by Hartmann et al. (227). In comparison with SCCs of the skin, the authors determined RAR receptors of 28 BCCs by RTq-PCR. Measured values of this study 
were also lowest for RAR $\beta$-mRNA $\left(7.91 \times 10^{-5}\right)$ and distinctly higher for RAR $\alpha\left(1.97 \times 10^{-3}\right)$ and RAR $\gamma\left(1.25 \times 10^{-2}\right)$.

Approximately comparable with regard to tumor-free margin tissues are immunohistochemical investigations by Reichrath et al. (228) on normal skin RAR- and RXR receptors of 12 male volunteers. Expression of RAR $\alpha$ was most distinctly detectable, among other things, in epidermal keratinocytes $(5+)$ and in hair follicle keratinocytes $(5+)$. Expression of RAR $\gamma$ was distinct in epidermal keratinocytes $(2+)$ and in hair follicles $(3+)$, but expression of RAR $\beta$ was found in traces only $(0$ to $1+)$. All three RXR receptors $R X R \alpha$, RXR $\beta$ and RXR $\gamma$ were distinctly expressed $(2+$, mostly $3+)$ in both of these cell types.

We therefore tested as well for expression of RAR and RXR receptors in small frozen sections of BCCs with immunohistochemical APAAP (105). After fixing pretreatment in a steamer, which was essential in our study for clear and strong nuclear receptor detection in frozen sections (162, cf. 106, 107), we applied antibodies from Santa Cruz / USA (anti-RAR $\alpha$, code sc551; anti-RXR $\beta 1$, code sc-556 and anti-RXR $\gamma$, code sc-555), from Abcam / USA (anti-RAR $\beta$, code ab15515) and from Abnova / USA (anti-RXR $\alpha$, code H00006256 M01). Other antibodies were less suitable for our frozen sections. In our study the anti-RAR $\gamma$ antibody was inappropriate (162). Evaluation succeeded with immunoreactive scores (IRS) as described with p53, Ki-67 and hTERT (2.3.1, 2.3.2 and 2.4.2). For control we investigated tissues with comparable localization from BCC-free patients. Figure 13 summarizes mean score values for

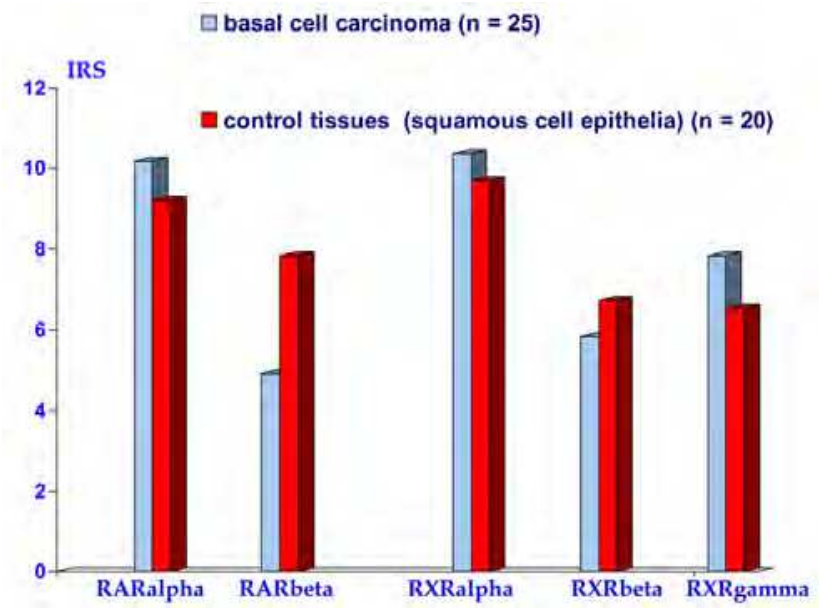

Fig. 13. Immunoreactive scores (IRS, cf. 144, 145) of expression for RAR and RXR receptors in small frozen sections of BCCs and control tissues (mean values).

expression of RAR and RXR receptors. In agreement with Kamradt and Reichrath (226) and with Hartmann (227) we were able to detect all receptors tested in BCCs in similar levels as in control tissues. RAR $\beta$ expression in BCCs had the lowest value (mean score value 4.92 \pm 1.81 ), followed by RXR $\beta$ (mean score value $5.83 \pm 1.76$ ), RXR $\gamma$ (mean score value $7.83 \pm 2.36$ ), RARa (mean score value 10.17 \pm 2.02 ) and $R X R \alpha$ (mean score value 10.38 \pm 2.14 ). Expression of RAR $\beta$ was almost significantly lower in BCCs than in control tissues $(p=0.056)$. The expression of the 
remaining receptors in BCCs and control tissues did not differ statistically: $p=0.586$ (RAR $\alpha$ ), $\mathrm{p}=0.862(\mathrm{RXR} \alpha), \mathrm{p}=0.863(\mathrm{RXR} \beta)$ and $\mathrm{p}=0.871(\mathrm{RXR} \gamma)$.

Our results suggest that the increase of RAR $\beta$ in the context of a chemoprevention might give us valuable information as a surrogate end point biomarker for the success of therapy in chemoprevention, as was previously demonstrated by Orlandi et al. (225). Figures 14a to $14 \mathrm{e}$ illustrate expression patterns of receptors in small frozen sections of basal cell carcinomas.

a) RAR $\alpha$

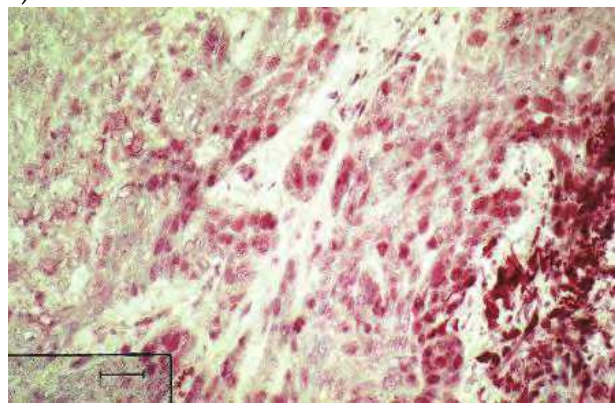

c) $\mathrm{RXR} \alpha$

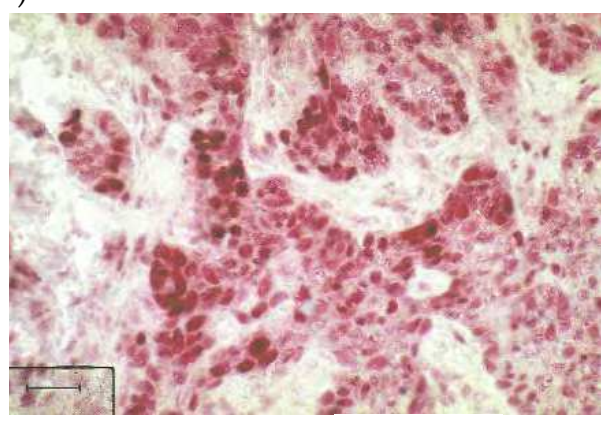

e) $\operatorname{RXR} \gamma$

\section{b)RAR $\beta$}

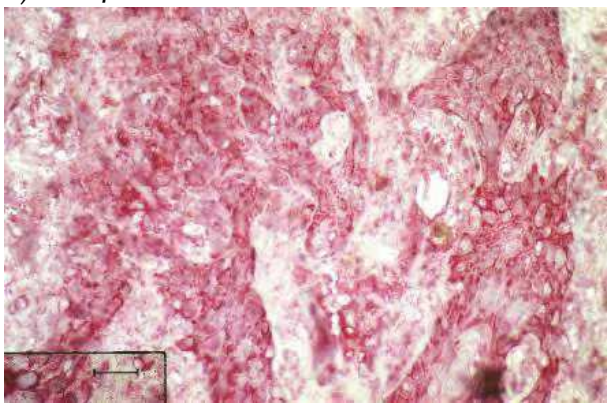

d) $\operatorname{RXR} \beta$

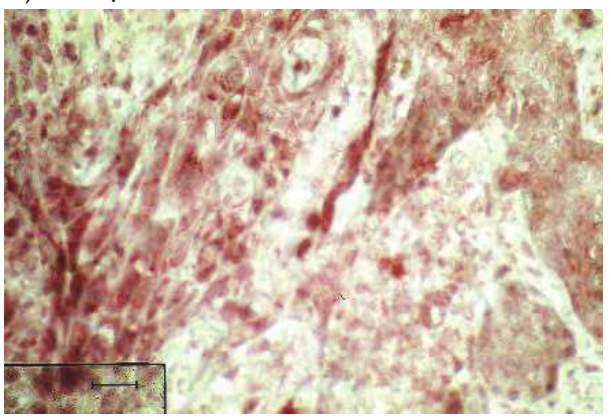

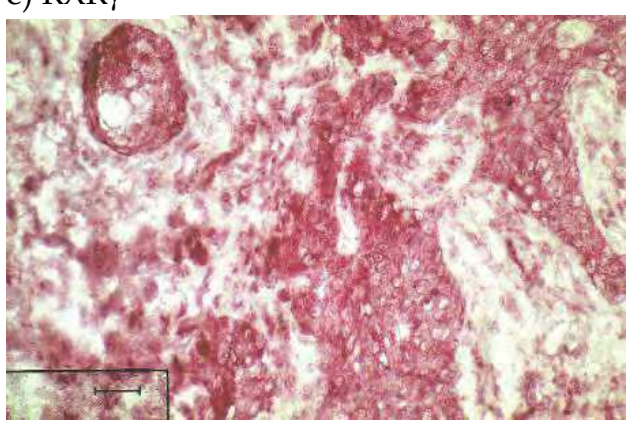

Fig. 14. Expression of retinoic acid receptors (RAR) and retinoid X receptors (RXR) of a nodular BCC (frozen sections); bars $20 \mu \mathrm{m}$. 


\section{Conclusion}

Immunohistochemical application of Ber-Ep4 (85 to 88) is particularly appropriate for histopathological differentiation between SCCs of the skin and basal cell carcinomas. When examined with immunohistochemical methods, adhesion molecules CD44v6 and U36 (CD44v6-chimera) give clear evidence for spreading of BCCs (Figure 4) and for the absence of tumor in tumor margins (91 to 96, 134 to 138, cf. 131 to 133). Radionuclide-labeled antibodies developed against oral squamous cell carcinomas $(146$ to $156,229,230)$ might also be applied in the diagnosis and therapy of patients with BCC.

It is important for prognostic purposes to make a clear distinction between smaller T1-BCCs and larger T2-BCCs (cf. 2. and Figure 2). Clinical classification into aggressive and less aggressive BCCs confirmed by histopathology can be supported, among other things, by markers p53 (101, 103, 121 to 124, 157 to 161), bcl-2 (81, 100, 122), Ki-67 (100, 106, 107, 158, 161) and by the apoptotic index (124). The markers Ki-67 and p53 can impart supplementary information and are important for histopathological diagnosis with regard to making a clinical judgement of the consequences of "tumor-free margin". Representation of telomerase activity in unfixed tumor margin tissues $(64,103,104,183)$, and not so much immunohistochemical proof of hTERT, $(98,107,189,192)$ can contribute to a better diagnostic assessment of tumor-free margins and may indicate early recurrence.

The high proportion of BCC recurrences is a challenge to develop better selective agents for chemoprevention and to support them with appropriate biomarkers such as Ki-67, apoptotic index, telomerase or by RAR $\beta(199,214,225$, cf. 162).

\section{Acknowledgements}

We are indebted to Prof. Swen O. Warnaar, CENTOCOR B.V. (Leiden/The Netherlands) for the generous gift of the MoAb U36 and MoAb E48 used in our studies. At our hospital Charité we thank Prof. Gustav-Paul Wildner for the histopathological evaluation of the small frozen sections and Mrs. Catherine Aubel for language help and editing. We thank Mrs. Ute Kruse-Boitschenko for her technical aid in the laboratory and Mr. Franz Hafner for the photo scanning. Our study was supported by grants from the Berlin Sparkasse Foundation for Medicine.

\section{References}

[1] Krüger, K.; Blume-Peytavi, U. \& Orfanos, C.E. (1999). Basal cell carcinoma possibly originates from the outer root sheath and/or the bulge region of the vellus hair follicle. Arch Dermatol Res 291: 253-259

[2] Lacour, J. (2002). Carcinogenesis of basal cell carcinomas: genetics and molecular mechanisms. Br J Dermatol 146: 17-19

[3] Tilli, C.M.; Van Steensel, M.A.; Krekels, G.A.; Neumann, H.A. \& Ramaekers, F.C. (2005). Molecular aetiology and pathogenesis of basal cell carcinoma. Br J Dermatol 152: 1108-1124

[4] Crowson, A.N. (2006). Basal cell carcinoma: biology, morphology and clinical implications. Mod Pathol 19: S127-S147

[5] Donovan, J. (2009). Review of the hair follicle origin hypothesis for basal cell carcinoma. Dermatol Surg 35: 1311-1323 
[6] Harris, P.J.; Takebe, N. \& Ivy, S.P. (2010). Molecular conversations and the development of the hair follicle and basal cell carcinoma. Cancer Prev Res (Phila) 3: 1217-1221

[7] Zackheim, H.S. (1964). Comparative cutaneous carcinogenesis in the rat. Differential response to the application of anthramine, methylcholanthrene, and dimethylbenzanthracene. Oncology 17: 236-246

[8] Bajdik, C.; Gallagher, R.; Astrakianakis, G.; Hill, G.; Fincham, S. \& McLean, D. (1996). Non-solar ultraviolet radiation and the risk of basal and squamous cell skin cancer. Br J Cancer 73: 1612-1614

[9] Nishigori, C. (2000). UV-induced DNA damage in carcinogenesis and its repair. J Dermatol Sci 23: S41-S44

[10] Ueda, M. (2000). Telomerase in cutaneous carcinogenesis. J Dermatol Sci 23: S37-S40

[11] Armstrong, B. \& Kricker, A. (2001). The epidemiology and UV induced skin cancer. J Photochem Photobiol B 63: 8-18

[12] Corona, R.; Dogliotti, E.; D'Errico, M.; Sera, F.; Iavarone, I.; Baliva, G.; Chinni, L.; Gobello, T.; Mazzanti, C.; Puddu, P. \& Pasquini, P. (2001). Risk factors for basal cell carcinoma in a mediterranean population - role of recreational sun exposure early in life. Arch Dermatol 137: 1162-1168; comment 1239-1240

[13] Tran, H.; Chen, K. \& Shumack, S. (2003). Epidemiology and aetiology of basal cell carcinoma. Br J Dermatol 149: 50-52

[14] Ramos, J.; Villa, J.; Ruiz, A.; Armstrong, R. \& Matta, J. (2004). UV dose determines key characteristics of nonmelanoma skin cancer. Cancer Epidemiol Biomarkers Prev 13: 2006-2011

[15] Boukamp, P. (2005). [UV-induced skin cancer: similarities-variations.] Durch UVStrahlung induzierte Hauttumore: Gemeinsamkeiten - Unterschiede. J Dtsch Dermatol Ges 3: 493-503

[16] Boukamp, P. (2005). Non-melanoma skin cancer: what drives tumor development and progression? Carcinogenesis 26: 1657-1667

[17] Nindl, I.; Gottschling, M. \& Stockfleth, E. (2007). Human papillomaviruses and nonmelanoma skin cancer: basic virology and clinical manifestations. Dis Markers 23: 247-259

[18] Rigel, D.S. (2008). Cutaneous ultraviolet exposure and its relationship to the development of skin cancer. J Am Acad Dermatol 58: S129-S132

[19] Greinert, R. (2009). Skin cancer: new markers for better prevention. Pathobiology 76: 64-81

[20] Kyrgidis, A.; Vahtsevanos, K.; Tzellos, T.G.; Xirou, P.; Kitikidou, K.; Antoniades, K.; Zouboulis, C.C. \& Triaridis, S. (2010). New concepts for basal cell carcinoma. Demographic, clinical, histological risk factors, and biomarkers. A systematic review of evidence regarding risk for tumor development, susceptibility for second primary and recurrence. J Surg Res 159: 545-556

[21] Kütting, B. \& Drexler, H. (2010). UV-induced skin cancer at workplace and evidencebased prevention. Int Arch Occup Environ Health 83: 843-854

[22] Patel, R.V.; Frankel, A. \& Goldenberg, G. (2011). An update on nonmelanoma skin cancer. J Clin Aesthet Dermatol 4: 20-27

[23] Göppner, D. \& Leverkus, M. (2011). Basal cell carcinoma: from the molecular understanding of the pathogenesis to targeted therapy of progressive disease. J Skin Cancer, Volume 2011, Article ID 650258, 8 pages 
[24] Golitz, L.E.; Norris, D.A.; Luekens, C.A. Jr \& Charles, D.M. (1980). Nevoid basal cell carcinoma syndrome. Multiple basal cell carcinomas of the palms after radiation therapy. Arch Dermatol 116: 1159-1163

[25] Howell, J.B. (1984). Nevoid basal cell carcinoma syndrome. Profile of genetic and environmental factors in oncogenesis. J Am Acad Dermatol 11: 98-104

[26] Gorlin, R.J. (1987). Nevoid basal-cell carcinoma syndrome. Medicine (Baltimore) 66 :98-113

[27] Miller, S.J. (1995). Etiology and pathogenesis of basal cell carcinoma. Clin Dermatol 13: 527-536

[28] Heagerty, A.; Smith, A.; English, J.; Lear, J.; Perkins, W.; Bowers, B.; Jones, P.; Gilford, J.; Alldersea, J.; Fryer, A. \& Strange, R.C. (1996). Susceptibility to multiple cutaneous basal cell carcinomas: significant interactions between glutathione S-transferase GSTM1 genotypes, skin type and male gender. Br J Cancer 73: 44-48

[29] Lear, J.; Tan, B.; Smith, A.; Bowers, W.; Jones, P.; Heagerty, A.; Strange, R. \& Fryer; A. (1997). Basal cell carcinoma. Risk factors for basal cell carcinoma in the UK: casecontrol study in 806 patients. J R Soc Med 90: 371-374

[30] Wallberg, P.; Kaaman, T. \& Lindberg, M.(1998). Multiple basal cell carcinomas. A clinical evaluation of risk factors. Acta Derm Venereol 78: 127-129

[31] Fusenig, N. \& Boukamp, P. (1998). Multiple stages and genetic alterations in immortalization, malignant transformation, and tumor progression of human skin keratinocytes. Mol Carcinog 23: 144-158

[32] Ramachandran, S.; Lear, J.T.; Ramsay, H.; Smith, A.G.; Bowers, B.; Hutchinson, P.E.; Jones, P.W.; Fryer, A.A. \& Strange, R.C. (1999). Presentation with multiple cutaneous basal cell carcinomas: association of glutathione S-transferase and cytochrome P450 genotypes with clinical phenotype. Cancer Epidemiol Biomarkers Prev 8: 61-67

[33] Sarasin, A. (1999). The molecular pathways of ultraviolet-induced carcinogenesis. Mutat Res 428: 5-10

[34] Ramachandran, S.; Fryer, A.; Smith, A.; Lear, J.; Bowers, B.; Griffiths, C.; Jones, P. \& Strange, R. (2000). Basal cell carcinoma. Tumor clustering is associated with incresed accrual in high risk subgroups. Cancer 89: 1012-1018

[35] Ramachandran, S.; Fryer, A.A.; Lovatt, T.; Lear, J.; Smith, A.G. \& Strange, R.C. (2001). Susceptibility and modifier genes in cutaneous basal cell carcinomas and their associations with clinical phenotype. J Photochem Photobiol B 63: 1-7

[36] Epstein, E. Jr. (2001). Genetic determinants of basal cell carcinoma risk. Med Pediatr Oncol 36: 555-558

[37] Madan, V.; Hoban, P.; Strange, R.C.; Fryer, A.A. \& Lear, J.T. (2006). Genetics and risk factors for basal cell carcinoma. Br J Dermatol 154: 5-7

[38] Roewert-Huber, J.; Lange-Asschenfeldt, B.; Stockfleth, E. \& Kerl, H. (2007). Epidemiology and aetiology of basal cell carcinoma. Brit J Dermatol 157 (Suppl. 2): 47-51

[39] Dessinioti, C.; Antoniou, C.; Katsambas, A. \& Stratigos, A.J. (2010). Basal cell carcinoma: what's new under the sun. Photochem Photobiol 86: 481-491

[40] Jones, E.A.; Sajid, M.I.; Shenton, A. \& Evans, D.G. (2011). Basal cell carcinomas in gorlin syndrome: a review of 202 patients. J Skin Cancer, Volume 2011, Article ID 217378, 6 pages

[41] Parren, L.J. \& Frank, J. (2011). Hereditary tumour syndromes featuring basal cell carcinomas. Br J Dermatol 165: 30-34 
[42] Vlajinac, H.; Adanja, B.; Lazar, Z.; Bogavac, A.; Bjekic, M.; Marinkovic, J. \& Kocev, N. (2000). Risk factors for basal cell carcinoma. Acta Oncol 39: 611-616

[43] Lock-Andersen, J.; Drzewiecki, K. \& Wulf, H. (1999). Eye and hair colour, skin type and constitutive skin pigmentation as risk factors for basal cell carcinoma and cutaneous malignant melanoma. A Danish case-control study. Acta Derm Venereol 79: 74-80

[44] de Villiers, E.; Lavergne, D.; McLaren, K. \& Benton, E. (1997). Prevailing papillomavirus types in non-melanoma carcinomas of the skin in renal allograft recipients. Int J Cancer 73: 356-361

[45] Harwood, C.A. \& Proby, C. (2002). Human papillomaviruses and non-melanoma skin cancer. Curr Opin Infect Dis 15: 101-114

[46] Stockfleth, E.; Nindl, I.; Sterry, W.; Ulrich, C.; Schmook, T. \& Meyer, T. (2004). Human papillomaviruses in transplant-associated skin cancers. Dermatol Surg 30: 604-609

[47] Hannuksela-Svahn, A.; Pukkala, E. \& Karvonen, J. (1999). Basal cell skin carcinoma and other nonmelanoma skin cancers in Finland from 1956 through 1995. Arch Dermatol 135: $781-786$

[48] Stern, R.S. (1999). The mysteries of geographic variability in nonmelanoma skin cancer incidence. Arch Dermatol 135: 843-844

[49] Staples, M.; Marks, R. \& Giles, G. (1998). Trends in the incidence of non-melanocytic skin cancer (NMSC) treated in Australia 1985-1995: are primary prevention programs starting to have an effect? Int J Cancer 78: 144-148

[50] Lear, W.; Dahlke, E. \& Murray, C.A. (2007). Basal cell carcinoma: review of epidemiology, pathogenesis, and associated risk factors. J Cutan Med Surg 11: 19-30

[51] Richmond-Sinclair, N.M.; Pandeya, N.; Ware, R.S.; Neale, R.E.; Williams, G.M.; van der Pols, J.C. \& Green, A.C. (2009). Incidence of basal cell carcinoma multiplicity and detailed anatomic distribution: longitudinal study of an Australian population. J Invest Dermatol 129: 323-328

[52] Richmond-Sinclair, N.M.; Pandeya, N.; Williams, G.M.; Neale, R.E.; van der Pols, J.C. \& Green, A.C. (2010). Clinical signs of photodamage are associated with basal cell carcinoma multiplicity and site: a 16-year longitudinal study. Int J Cancer 127: 26222629

[53] Flohil, S.C.; de Vries, E.; Neumann, H.A.; Coebergh, J.W. \& Nijsten, T. (2011). Incidence, prevalence and future trends of primary basal cell carcinoma in the Netherlands. Acta Derm Venereol 91: 24-30

[54] Sander, C.S.; Hamm, F.; Elsner, P. \& Thiele, J.J. (2003). Oxidative stress in malignant melanoma and non-melanoma skin cancer. Br J Dermatol 148: 913-922

[55] de Gruijl, F.; van Kranen, H. \& Mullenders, L. (2001). UV-induced DNA damage, repair, mutations and oncogenic pathways in skin cancer. J Photochem Photobiol B 63: 19-27

[56] de Gruijl, F. (2002). Photocarcinogenesis: UVA vs. UVB radiation. Skin Pharmacol Appl Skin Physiol 15: 316-320

[57] Burnworth, B.; Arendt, S.; Muffler, S.; Steinkraus, V.; Brocker, E. B.; Birek, C.; Hartschuh, W.; Jauch, A. \& Boukamp, P. (2007). The multi-step process of human skin carcinogenesis: A role for p53, cyclin D1, hTERT, p16, and TSP-1. Eur J Cell Biol 86: 763-780

[58] Slaughter, D.; Southwick, H. \& Smejkal, W. (1953). "Field cancerization" in oral stratified squamous epithelium. Cancer 6: 963-968 
[59] Mertens, F.; Heim, S.; Mandahl, N.; Johansson, B.; Mertens, O.; Persson, B.; Salemark, L.; Wennerberg, J.; Jonsson, N. \& Mitelman, F. (1991) Cytogenetic analysis of 33 basal cell carcinomas. Cancer Res 51: 954-957

[60] Kanjilal, S.; Strom, S.S.; Clayman, G.L.; Weber, R.S.; El-Naggar, A.K.; Kapur, V.; Cummings, K.K.; Hill, L.A.; Spitz, M.R.; Kripke, M.L. \& Ananthaswamy, N. (1995). p53 mutations in nonmelanoma skin cancer of the head and neck: molecular evidence for field cancerization. Cancer Res 55: 3604-3609

[61] Carlson, J.A.; Scott, D.; Wharton, J. \& Sell, S. (2001). Incidental histopathologic patterns: Possible evidence of 'field cancerization' surrounding skin tumors. Amer J Dermatopathol 23: 494-496

[62] Stern, R.; Bolshakov, S.; Nataraj, A. \& Ananthaswamy, H. (2002). p53 mutation in nonmelanoma skin cancers occurring in psoralen ultraviolet A-treated patients: Evidence for heterogeneity and field cancerization. J Invest Dermatol 119: 522-526

[63] Ulrich, C.; Kanitakis, J.; Stockfleth, E. \& Euvrard, S. (2008). Skin cancer in organ transplant recipients--where do we stand today? Am J Transplant 8: 2192-2198

[64] Ueda, M.; Ouhtit, A.; Bito, T.; Nakazawa, K.; Lübbe, J.; Ichihashi, M.; Yamasaki, H. \& Nakazawa, H. (1997). Evidence for UV-associated activation of telomerase in human skin. Cancer Res 57: 370-374

[65] Hollstein, M.; Sidransky, D.; Vogelstein, B. \& Harris, C.C. (1991). p53 mutations in human cancers. Science 253: 49-53

[66] Lane, D.P. (1992). p53, guardian of the genome. Nature 358: 15-16

[67] Haupt, S.; Berger, M.; Goldberg, Z. \& Haupt, Y. (2003). Apoptosis - the p53 network. J Cell Sci 116: 4077-4085

[68] Wyllie, A.H. (1993). Apotptose (The 1992 Frank Rose Memorial Lecture). Br J Cancer 67: 205-208

[69] Cadwell, C. \& Zambetti, G.P. (2001). The effects of wild-type p53 tumor suppressor activity and mutant p53 gain-of-function on cell growth. Gene 277: 15-30

[70] Shen, Y. \& White, E. (2001). p53-dependent apoptosis pathways. Adv Cancer Res 82: 55-84

[71] Fadeel, B. \& Orrenius, S. (2005). Apoptosis: a basic biological phenomenon with wideranging implications in human disease. J Intern Med 258: 479-517

[72] Foijer, F. \& te Riele, H. (2006). Check, double check: the G2 barrier to cancer. Cell Cycle 5: 831-835

[73] Zilfou, J.T. \& Lowe, S.W. (2009). Tumor suppressive functions of p53. Cold Spring Harb Perspect Biol 1: 00: a001883

[74] Tapia, N. \& Schöler, H.R. (2010). p53 connects tumorigenesis and reprogramming to pluripotency. J Exp Med 207: 2045-2048

[75] Sun, W. \& Yang, J. (2010). Functional mechanisms for human tumor suppressors. J Cancer 1: 136-140

[76] Ryan, K.M. (2011). p53 and autophagy in cancer: guardian of the genome meets guardian of the proteome. Eur J Cancer 47: 44-50

[77] Strasser, A.; Harris, A.; Jacks, T. \& Cory, S. (1994). DNA damage can induce apoptosis in proliferating lymphoid cells via p53-independent mechanisms inhibitable by bcl2. Cell 79: 329-339

[78] Chiou, S.-K.; Rao, L. \& White, E. (1994). Bcl-2 blocks p53-dependent apoptosis. Mol Cell Biol 14: 2556-2563

[79] Norris, D.A. (1995). Differential control of cell death in the skin. Arch Dermatol 131: 945-948 
[80] Delehedde, M.; Cho, S.; Sarkiss, M.; Brisbay, S.; Davies, M.; El-Naggar, A. \& McDonnell, T. (1999). Altered expression of bcl-2 family member proteins in nonmelanoma skin cancer. Cancer 85: 1514-1422

[81] Ramdial, P.; Madaree, A.; Reddy, R. \& Chetty, R. (2000). Bcl-2 protein expression in aggressive and non-aggressive basal cell carcinomas. J Cutan Pathol 27: 283-291

[82] Dicker, T.; Siller, G. \& Saunders, N. (2002). Molecular and cellular biology of basal cell carcinoma. Australas J Dermatol 43: 241-246

[83] Vega-Memije, E.; De Larios, N.; Waxtein, L. \& Dominguez-Soto, L. (2000). Cytodiagnosis of cutaneous basal and squamous cell carcinoma. Int J Dermatol 39: 116-120

[84] Christensen, E.; Bofin, A.; Gudmundsdóttir, I. \& Skogvoll, E. (2008). Cytological diagnosis of basal cell carcinoma and actinic keratosis, using Papanicolaou and May-Grünwald-Giemsa stained cutaneous tissue smear. Cytopathology 19: 316-322

[85] Tellechea, O.; Reis, J.; Domingues, J. \& Baptista, A. (1993). Monoclonal antibody Ber EP4 distinguishes basal-cell carcinoma from squamous-cell carcinoma of the skin. Am J Dermatopathol 15: 452-455

[86] Beer, T.; Shepherd, P. \& Theaker, J. (2000). Ber EP4 and epithelial membrane antigen aid distinction of basal cell, squamous cell and basosquamous carcinomas of the skin. Histopathology 37: 218-223

[87] Swanson, P.; Fitzpatrick, M.; Ritter, J.; Glusac, E. \& Wick, M. (1998). Immunohistologic differential diagnosis of basal cell carcinoma, squamous cell carcinoma, and trichoepithelioma in small cutaneous biopsy specimens. J Cutan Pathol 25: 153-159

[88] Tope, W.; Nowfear-Rad, M. \& Kist, D. (2000). Ber-Ep4-positive phenotype differentiates actinic keratosis from superficial basal cell carcinoma. Dermatol Surg 26: 415-418

[89] Yada, K.; Kashima, K.; Daa, T.; Kitano, S.; Fujiwara, S. \& Yokoyama, S. (2004). Expression of CD10 in basal cell carcinoma. Am J Dermatopathol 26: 463-471

[90] Aiad, H.A. \& Hanout, H.M. (2007). Immunohistochemical Expression of CD10 in Cutaneous Basal and Squamous Cell Carcinomas. J Egypt Natl Canc Inst 19: 195-201

[91] Guttinger, M.; Sutti, F.; Barnier, C.; McKay, C. \& Berti, E. (1995). Expression of CD44 standard and variant forms in skin tumors. Loss of CD44 correlates with aggressive potential. Eur J Dermatol 5: 398-406

[92] Seelentag, W.K.F.; Günthert, U.; Saremaslani, P.; Futo, E.; Pfaltz, M.; Heitz, P.U. \& Roth. J. (1996). CD44 standard and variant isoform expression in human epidermal skin tumors is not correlated with tumor aggressiveness but down-regulated during proliferation and tumor de-differentiation. Int J Cancer (Pred Oncol) 69: 218-224

[93] Dietrich, A.; Tanczos, E.; Vanscheidt, W.; Schopf, E. \& Simon J. (1997). Detection of CD44 splice variants in formalin fixed, paraffin-embedded specimens of human skin cancer. J Cutan Pathol 24: 37-42

[94] Seiter, S.; Tilgen, W.; Herrmann, K.; Schadendorf, D.; Patzelt, E.; Möller, P. \& Zöller, M. (1996). Expression of CD44 splice variants in human skin and epidermal tumours. Virchows Arch 428: 141-149

[95] Simon, J.; Heider, K.-H.; Dietrich, A.; Wuttig, C.; Schöpf, E.; Adolf, G.; Ponta, H. \& Herrlich, P. (1996). Expression of CD44 isoforms in human skin cancer. Eur J Cancer 32A: 1394-1400

[96] Son, K.D.; Kim, T.J.; Lee, Y.S.; Park, G.S.; Han, K.T.; Lim, J.S. \& Kang, C.S. (2008). Comparative analysis of immunohistochemical markers with invasiveness and histologic differentiation in squamous cell carcinoma and basal cell carcinoma of the skin. J Surg Oncol 97: 615-620 
[97] Al- Sader, M.; Doyle, E.; Kay, E.; Bennett, M.; Walsh, C.; Curran, B.; Milburn, C. \& Leader, M. (1996). Proliferation indexes A comparison between cutaneous basal and squamous cell carcinomas. J Clin Pathol 49: 549-551

[98] Park, H.R.; Min, S.K.; Cho, H.D.; Kim, K.H.; Shin, H.S. \& Park, Y.E. (2004). Expression profiles of p63, p53, survivin, and hTERT in skin tumors. J Cutan Pathol 31: 544-549

[99] Bäckvall, H.; Wolf, O.; Hermelin, H.; Weitzberg, E. \& Pontén, F. (2004). The density of epidermal p53 clones is higher adjacent to squamous cell carcinoma in comparison with basal cell carcinoma. Br J Dermatol 150: 259-266

[100] Chang, C.; Tsai, R.; Chen, G.; Yu, H. \& Chai, C. (1998). Expression of bcl-2, p53 and Ki67 in arsenical skin cancers. J Cutan Pathol 25: 457-462

[101] Bolshakov, S.; Walker, C.; Strom, S.; Selvan, M.; Clayman, G.; El-Naggar, A.; Lippman, S.; Kripke, M. \& Ananthaswamy, H. (2003). p53 mutations in human aggressive and nonaggressive basal and squamous cell carcinomas. Clin Cancer Res 9: 228-234

[102] Fabricius, E.-M.; Gurr, U. \& Wildner, G.-P. (2002). Telomerase activity levels in the surgical margin and tumour distant tissue of the squamous cell carcinoma of the head-and-neck. Anal Cell Pathol 24: 25-39

[103] Fabricius, E.-M.; Bezeluk, A.; Kruse-Boitschenko, U.; Wildner, G.-P. \& Klein, M. (2003). Clinical significance of telomerase activity in basal cell carcinomas and in tumourfree surgical margins. Int J Oncol 23: 1389-1399

[104] Fabricius, E.-M. (2006). The role of telomerase for cancerogenesis of basal cell and squamous cell carcinomas. In: Reichrath J (ed.): Molecular Mechanisms of Basal Cell and Squamous Cell Carinomas, New York, Landes Bioscience and Springer Science + Bisness Media Inc., pp 115-133, ISBN 0-387-26046-3

[105] Cordell, J.L.; Falini, B.; Erber, W.N.; Ghosh, A.K.; Abdulaziz, Z.; MacDonald, S.; Pulford, K.A F.; Stein, H. \& Mason, D.Y. (1984). Immunoenzymatic labeling of monoclonal antibodies using immune complexes of complexes of alkaline phosphatase and monoclonal anti-alkine phosphatase (APAAP Complexes). J Histochem Cytochem 32: 219-229

[106] Fabricius, E.-M.; Kruse-Boitschenko, U.; Khoury, R.; Wildner, G.-P.; Raguse, J.-D. \& Klein, M. (2009). Immunohistochemical determination of the appropiate anti-hTERT antibodies for in situ detection of telomerase activity in frozen sections of head and neck squamous cell carcinomas and tumor margin tissues. Int J Oncol 34: 1257-1279

[107] Fabricius. E.-M.; Kruse-Boitschenko, U.: Khoury, R.; Wildner, G.-P.; Raguse, J.-D.; Klein, M. \& Hoffmeister, B. (2009). Localization of telomerase hTERT protein in frozen sections of basal cell carcinomas (BCC) and tumor margin tissues. Int J Oncol 35: $1377-1394$

[108] Friedman, H.; Williams, T.; Zamora , S. \& al Assaad, Z. (1997). Recurrent basal cell carcinoma in margin-positive tumors. Ann Plast Surg 38: 232-235

[109] Rippey, J. \& Rippey, E. (1997). Characteristics of incompletely excised basal cell carcinomas of the skin. Med J Aust 166: 581-583

[110] Robinson, J. \& Fisher, S. (2000). Recurrent basal cell carcinoma after incomplete resection. Arch Dermatol 136: 1318-1324

[111] Fleischer, A. J.; Feldman. S.; Barlow, J.; Zheng, B.; Hahn, H.; Chuang, T.; Draft, K.; Golitz, L.; Wu, E.; Katz, A.; Maize, J.; Knapp, T. \& Leshin, B. (2001). The specialty of the treating physician affects the likelihood of tumor-free resection margins for basal cell carcinoma: results from a multi-institutional retrospective study. J Am Acad Dermatol 44: 224-230 
[112] Bisson, M.; Dunkin, C.; Suvarna, S. \& Griffiths, R. (2002). Do plastic surgeons resect basal cell carcinomas too widely? A prospective study comparing surgical and histological margins. Brit J Plast Surg 55: 293-297

[113] Nagore, E.; Grau, C.; Molinero, J. \& Fortea, J.M. (2003). Positive margins in basal cell carcinoma: relationship to clinical features and recurrence risk. A retrospective study of 248 patients. J Eur Acad Dermatol Venereol 17: 167-170

[114] Gulleth, Y.; Goldberg, N.; Silverman, R.P \& Gastman, B.R. (2010). What is the best surgical margin for a basal cell carcinoma: a meta-analysis of the literature. Plast Reconstr Surg 126: 1222-1231

[115] Wittekind, Ch.; Meyer, H.J. \& Bootz, F. (Eds) (2005). TNM Klassifikation maligner Tumoren. UICC International Union Against Cancer. 6. Aufl. Korr. Nachdruck. Hauttumoren. 111-116

[116] Vico, P.; Fourez, T.; Nemec, E.; Andry, G. \& Deraemaecker, R. (1995). Aggressive basal cell carcinoma of head and neck areas. Eur J Surg Oncol 21: 490-497

[117] Rippey, J. (1998). Why classify basal cell carcinomas? Histopathology 32: 393-398

[118] De Rosa, G.; Vetrani, A.; Zeppa, P.; Zabatta, A.; Barra, E.; Gentile, R.; Fulciniti, F.; Troncone, G.; die Benedetto, G. \& Palombini, L. (1990). Comparative morphometric analysis of aggressive and ordinary basal cell carcinoma of the skin. Cancer 65: 544549

[119] De Rosa, G.; Staibano, S.; Barra, E.; Zappa, P.; Salvatore, G.; Vetrani, A. \& Palombini, L. (1992). Nucleolar organizer regions in aggressive and nonaggressive basal cell carcinoma of the skin. Cancer 69: 123-126

[120] Raasch, B.A.; Buettner, P.G. \& Garbe, C. (2006). Basal cell carcinoma: histological classification and body-site distribution. Br J Dermatol 155: 401-407

[121] Ansarin, H.; Daliri, M. \& Soltani-Arabshahi, R. (2006). Expression of p53 in aggressive and non-aggressive histologic variants of basal cell carcinoma. Eur J Dermatol 16: 543-547

[122] Staibano, S.; Lo Muzio, L.; Pannone, G.S.M.; Salvatore, G.; Errico, M.; Fanali, S.; De Rosa, G. \& Piattelli, A. (2001). Interaction between bcl-2 and p53 in neoplastic progression in basal cell carcinoma of the head and neck. Anticancer Res 21: 37573764

[123] Staibano, S.; Lo Muzio, L.; Pannone, G.; Somma, P.; Farronato, G.; Franco, R.; Bambini, F.; Serpico, R. \& De Rosa, G. (2001). P53 and hMSH2 expression in basal cell carcinomas and malignant melanomas from photoexposed areas of head and neck region. Int J Oncol 19: 551-559

[124] Staibano, S.; Lo Muzio, L.; Mezza, E.; Argenziano, G.; Tornillo, L.; Pannone, G. \& De Rosa, G. (1999). Prognostic value of apoptotic index in cutaneous basal cell carcinomas of head and neck. Oral Oncol 35: 541-547

[125] Staibano, S.; Lo Muzio, L.; Pannone, G.; Mezza, E.; Argenziano, G.; Vetrani, A.; Lucariello, A.; Franco, R.; Errico, M. \& DeRosa, G. (2001). DNA ploidy and cyclin D1 expression in basal cell carcinoma of the head and neck. Am J Clin Pathol 115: 805-813

[126] Staibano, S.; Boscaino, A.; Salvatore, G.; Orabona, P.; Palombini, L. \& De Rosa, G. (1996). The prognostic significance of tumor angiogenesis in nonaggressive and aggressive basal cell carcinoma of the human skin. Hum Pathol 27: 695-700 
[127] Günthert, U. (1993). CD44: A multitude of isoforms with diverse functions. Curr Top Microbiol Immunol 184: 47-63

[128] Naor, D.; Sionov, R. \& Ish-Shalom, D. (1997). CD44: Structure, function, and association with the malignant process. Adv Cancer Res 71: 241-319

[129] Naor, D.; Sionov, R.V. \& Ish-Shalom, D. (2002). CD44 in cancer. Crit Rev Clin Lab Sci 39: 527-579

[130] Hyckel, P.; Kosmehl, H.; Berndt, A.; Hesse, J.; Stiller, K.J. \& Robotta, C. (1995). Immunohistochemische Demonstration von CD $44 \mathrm{H}, \mathrm{CD} 44 \mathrm{v} 3$ und CD $44 \mathrm{v} 6 \mathrm{im}$ oralen Plattenepithelkarzinom. Dtsch Z Mund Kiefer GesichtsChir 19: 284-289

[131] Fabricius, E.-M.; Langford, A.; Bier, J.; Hell, B.; Wildner, G.-P. \& Blümcke, S. (1997). Immunohistochemical characterization of E48 and CD44-v6 expression in head and neck carcinomas. Cancer J 10: 325-330

[132] Fabricius, E.-M.; Guschmann, M.; Wildner, G.-P.; Langford, A.; Hell, B. \& Bier J. (1998). Divergent immunohistochemical E48 and CD44-v6 antigen expression patterns between lymph node metastases and primary squamous cell carcinomas in the head and neck region. Cancer J 11: 325-330

[133] Fabricius, E.-M.; Guschmann, M.; Langford, A.; Hell, B. \& Bier, J. (2000). Immunohistochemical assessment of the tumour-associated epitopes CD44v6 and E48 in tumour-free lymph nodes from patients with squamous cell carcinoma in the head-neck region. Anal Cell Pathol 20: 115-129

[134] Salmi, M.; Grön-Virta, K.; Sointu, P.; Grenman, R.; Kalimo, H. \& Jalkanen, S. (1993). Regulated expression of exon v6 containing isoforms of CD44 in man: downregulation during malignant tranformation of tumors of squamocellular origin. J Cell Biol 122: 431-442

[135] Baum, H.P.; Schmid, T.; Shock, G. \& Reichrath, J. (1996). Expression of CD44 isoforms in basal cell carcinomas. Br J Dermatol 134: 465-468

[136] Kooy, A.; Tank, B.; de Jong, A.; Vuzevski, V.; van der Kwast, T. \& van Joost, T. (1999). Expression of E-cadherin, alpha- \& beta-catenin, and CD44V6 and the subcellular localization of E-cadherin and CD44V6 in normal epidermis and basal cell carcinoma. Hum Pathol 30: 1328-1335

[137] Dingemans, K.; Ramkema, M.; Koopman, G.; Van Der Wal, A.; Das, P. \& Pals, S. (1999). The expression of CD44 glycoprotein adhesion molecules in basal cell carcinomas is related to growth pattern and invasiveness. Br J Dermatol 140: 17-25

[138] Dingemans, K.; Ramkema, M. \& Pals, S. (2002). CD44 is exposed to the extracellular matrix at invasive sites in basal cell carcinomas. Lab Invest 82: 313-322

[139] Schrijvers, A.H.G.J.; Gerretsen, M.; Fritz, J.M. ; van Walsum, M.; Quak, J. J.; Snow, G.B. \& van Dongen, G.A.M. S. (1991). Evidence for a role of the monoclonal antibody E48 defined antigen in cell-cell adhesion in squamous epithelia and head and neck squamous cell carcinoma. Exper Cell Res 196: 264-269

[140] Quak, J.J.; Balm, A.J.M.; van Dongen, G .A.M. S.; Brakkee, J.G.P.; Scheper, R. J.; Snow, G.B. \& Meijer, C. J.M. (1990). A 22-kd surface antigen detected by monoclonal antibody E 48 is exlusively expressed in stratified squamous and transitional epithelia. Am J Pathol 136: 191-197

[141] Schrijvers, A.H.; Quak, J.J.; Uyterlinde, A.M.; van Walsum, M.; Meijer, C.J.; Snow, G.B. \& van Dongen, G.A. (1993). MAb U36, a novel monoclonal antibody successful in 
immunotargeting of squamous cell carcinoma of the head and neck. Cancer Res 53: 4383-4390

[142] van Hal, N.L.W.; van Dongen, G.A.M.S.; Rood-Knippels, E.M.C.; van Valk, P.; Snow, G.B. \& Brakenhoff, R.H. (1996). Monoclonal antibody U36, a suitable candidate for clinical immunotherapy of squamous-cell carcinoma, recognizes a CD44 isoform. Int J Cancer 68: 520-527

[143] Van Hal, N.; van Dongen, G.; TenBrink, C.; Herron, J.; Snow, G. \& Brakenhoff, R. (1997). Sequence variation in the monoclonal-antibody-U36-defined CD44v6 epitope. Cancer Immunol Immunother 45: 88-92

[144] Remmele, W.; Hildebrand, U.; Hienz, H.A.; Klein, P.-J.; Vierbuchen, M.; Behnken, L.J.; Heicke, B. \& Scheidt, E. (1986). Comparative histological, histochemical, immunohistochemical and biochemical studies on oestrogen receptors, lectin receptors, and Barr bodies in human breast cancer. Virchows Arch (Pathol Anat) 409: 127-147

[145] Remmele, W. \& Stegner, H.E. (1987). Vorschlag zur einheitlichen Definition eines immunreaktiven Scores (IRE) für den immunhistochemischen ÖstrogenrezeptorNachweis (ER-ICA) im Mammagewebe. Pathologie 8: 138-140

[146] de Bree, R.; Ross, J.; Quak, J.; den Hollander, W.; Snow, G. \& van Dongen, G. (1995). Radioimmunoscintigraphy and biodistribution of technetium-99m-labeled monoclonal antibody U36 in patient with head and neck cancer. Clin Cancer Res 1: 591-598

[147] Börjesson, P.K.; Postema, E.J.; de Bree, R.; Roos, J.C.; Leemans, C.R.; Kairemo, K.J. \& van Dongen, G.A. (2004). Radioimmunodetection and radioimmunotherapy of head and neck cancer. Oral Oncol 40: 761-772

[148] Colnot, D.R.; Nieuwenhuis, E.J.; Kuik, D.J.; Leemans, C.R.; Dijkstra, J.; Snow, G.B.; van Dongen, G.A. \& Brakenhoff, R.H. (2004). Clinical significance of micrometastatic cells detected by E48 (Ly-6D) reverse transcription-polymerase chain reaction in bone marrow of head and neck cancer patients. Clin Cancer Res 10: 7827-7833

[149] Börjesson, P.K.; Jauw, Y.W.; Boellaard, R.; de Bree, R.; Comans, E.F.; Roos, J.C.; Castelijns, J.A.; Vosjan, M.J.; Kummer, J.A.; Leemans, C.R.; Lammertsma, A.A. \& van Dongen, G.A. (2006). Performance of immuno-positron emission tomography with zirconium-89-labeled chimeric monoclonal antibody U36 in the detection of lymph node metastases in head and neck cancer patients. Clin Cancer Res 12: 21332140

[150] Fortin, M.A.; Salnikov, A.V.; Nestor, M.; Heldin, N.E.; Rubin, K. \& Lundqvist, H. (2007). Immuno-PET of undifferentiated thyroid carcinoma with radioiodinelabelled antibody cMAb U36: application to antibody tumour uptake studies. Eur J Nucl Med Mol Imaging 34: 1376-1387

[151] Sandström, K.; Nestor, M.; Ekberg, T.; Engström, M.; Anniko, M. \& Lundqvist, H. (2008). Targeting CD44v6 expressed in head and neck squamous cell carcinoma: preclinical characterization of an 111In-labeled monoclonal antibody. Tumour Biol 29: 137-144

[152] Börjesson, P.K.; Jauw, Y.W.; de Bree, R.; Roos, J.C.; Castelijns, J.A.; Leemans, C.R.; van Dongen, G.A. \& Boellaard, R.(2009). Radiation dosimetry of $89 \mathrm{Zr}$-labeled chimeric monoclonal antibody U36 as used for immuno-PET in head and neck cancer patients. J Nucl Med 50: 1828-1836 
[153] de Bree, R.; Roos, J.; Plaizier, M.; Quak, J.; van Kamp, G.; den Hollander, W.; Snow, G. \& van Dongen, G. (1997). Selection of monoclonal antibody E48 IgG or U36 IgG for adjuvant radioimmunotherapy in head and neck cancer patients. Brit J Cancer 75: 1049-1060

[154] Colnot, D.R.; Quak, J.J.; Roos, J.C.; van Lingen, A.; Wilhelm, A.J.; van Kamp, G.J.; Huijgens, P.C.; Snow, G.B. \& van Dongen, G.A. (2000). Phase I therapy study of 186Re-labeled chimeric monoclonal antibody U36 in patients with squamous cell carcinoma of the head and neck. J Nucl Med 41: 1999-2010

[155] Börjesson, P.K.; Postema, E.J.; Roos, J.C.; Colnot, D.R.; Marres, H.A.; van Schie, M.H.; Stehle, G.; de Bree, R.; Snow, G.B.; Oyen, W.J. \& van Dongen, G.A. (2003). Phase I therapy study with (186)Re-labeled humanized monoclonal antibody BIWA 4 (bivatuzumab) in patients with head and neck squamous cell carcinoma. Clin Cancer Res 9: 3961S-3972S

[156] Colnot, D.R.; Roos, J.C.; de Bree, R.; Wilhelm, A.J.; Kummer, J.A.; Hanft, G.; Heider, K.H.; Stehle, G.; Snow, G.B.; \& van Dongen, G.A. (2003). Safety, biodistribution, pharmacokinetics, and immunogenicity of $99 \mathrm{mTc}$-labeled humanized monoclonal antibody BIWA 4 (bivatuzumab) in patients with squamous cell carcinoma of the head and neck. Cancer Immunol Immunother 52: 576-582

[157] Urano, Y.; Assano, T.; Yoshimoto, K.; Iwahana, H.; Kubu, Y.; Kato, S.; Sasaki, S.; Takeuchi, N.; Uchida, N.; Nakanishi, H.; Arase, S. \& Itakura, M. (1995). Frequent p53 accumulation in the chronically sun-exposed epidermis and clonal expansion of p53 mutant cells in the epidermis adjacent to basal cell carcinoma. J Invest Dermatol 104: 928-932

[158] Barrett, T.L.; Smith, K.J.; Hodge, J.J.; Butler, R.; Hall, F.W. \& Skelton, H.G. (1997). Immunohistochemical nuclear staining for p53, PCNA, and Ki-67 in different histologic variants of basal cell carcinoma. J Am Acad Dermatol 37: 430-437

[159] Demirkan, N.; Colakoglu, N. \& Duzcan, E. (2000). Value of p53 protein in biological behavior of basal cell carcinoma and in normal epithelia adjacent to carcinomas. Pathol Oncol Res 6: 272-274

[160] Rajabi, M.A.; Rajabi, P. \& Afshar-Moghaddam, N. (2006). Determination of p53 expression in basal cell carcinoma tissues and adjacent nontumoral epidermis from sun-exposed areas of the head and neck. Arch Iran Med 9: 46-48

[161] Koseoglu, R.D.; Sezer, E.; Eyibilen, A.; Aladag, I. \& Etikan, I. (2009). Expressions of p53, cyclinD1 and histopathological features in basal cell carcinomas. J Cutan Pathol 36: 958-965

[162] Fabricius, E.-M.; Kruse-Boitschenko, U.; Schneeweiss, U.; Wildner, G.-P; Hoffmeister, B. \& Raguse, J.-D. (2011). Model examination of chemoprevention with retinoids in squamous cell carcinomas of the head and neck region and suitable biomarkers for chemoprevention. Int J Oncol 39: 1083-1097

[163] Healy, E.; Angus, B.; Lawrence, C.M. \& Rees, J.L. (1995). Prognostic value of Ki67 antigen expression in basal cell carcinomas. Br J Dermatol 133: 737-741

[164] Abdelsayed, R.A.; Guijarro-Rojas, M.; Ibrahim, N.A. \& Sangueza, O.P. (2000). Immunohistochemical evaluation of basal cell carcinoma and trichepithelioma using bcl-2, Ki67, PCNA and p53. J Cutan Pathol 27: 169-175

[165] Greider, C. \& Blackburn, E. (1987). The telomere terminal transferase of Tetrahymena is a ribonucleoprotein enzyme with two kinds of primer specificity. Cell 51: 887-898 
[166] Greider, C. \& Blackburn, E. (1995). Identification of a specific telomere terminal transferase activity in Tetrahymena extracts. Cell 43: 405-413

[167] Hayflick, L. \& Moorhead, P. (1961). The serial cultivation of human diploid cell strains. Exper Cell Res 25: 585-624

[168] Kim, N.W.; Piatyszek, M.A.; Prowse, K.R.; Harley, C.B.; West, M.D.; Ho, P.L.C.; Coviello, G.M.; Wright, W.E.; Weinrich, S.L. \& Shay, J.W. (1994) Specific association of human telomerase activity with immortal cells and cancer. Science 266: 2011-2015

[169] Wright, W.; Piatyszek, M.R.W.; Byrd, W. \& Shay, J. (1996). Telomerase activity in human germline and embryonic tissues and cells. Dev Genet 18: 173-179

[170] Hiyama, K.; Hirai, Y.; Kyoizumi, S.; Akiyama, M.; Hiyama, E.; Piatyszek, M.-A.; Shay, J.-W.; Ishioka, S. \& Yamakido, M. (1995). Activation of telomerase in human lymphocytes and hematopoietic progenitor cells. J Immunol 155: 3711-3715

[171] McKenzie, K.; Umbricht, C. \& Sukumar, S. (1999). Applications of telomerase research in the fight against cancer. Mol Med Today 5: 114-122

[172] Meyerson, M. (2000). Role of telomerase in normal and cancer cells. J Clin Oncol 18: 2626-2634

[173] Ramirez, R.; Wright, W.; Shay, J. \& Taylor, R. (1997). Telomerase activity concentrates in the mitotically active segments of human hair follicles. J Invest Dermatol 108: 113-117

[174] Matthews, P. \& Jones, C. (2001). Clinical implications of telomerase detection. Histopathology 38: 485-498

[175] Hoogduijn, M.J.; Gorjup, E. \& Genever, P.G. (2006). Comparative characterization of hair follicle dermal stem cells and bone marrow mesenchymal stem cells. Stem Cells Dev 15: 49-60

[176] Bodnar, A.; Kim, N.; Effros, R. \& Chiu, C.-P. (1996). Mechanism of telomerase induction during T cell activation. Exp Cell Res 228: 58-64

[177] Mimeault, M. \& Batra, S.K. (2010). Recent advances on skin-resident stem/progenitor cell functions in skin regeneration, aging and cancers and novel anti-aging and cancer therapies. J Cell Mol Med 14: 116-134

[178] Effros, R.B. (2011). Telomere/telomerase dynamics within the human immune system: effect of chronic infection and stress. Exp Gerontol 46: 135-140

[179] de Lange, T. (1994). Activation of telomerase in a human tumor. Proc Natl Acad Sci USA 91: 2882-2885

[180] Shay, J. \& Wright, W. (1996). The reactivation of telomerase activity in cancer progression. Trends Genetic 12: 129-131

[181] Shay, J. \& Bacchetti, S. (1997). A survey of telomerase activity in human cancer. Eur J Cancer 33: 787-791

[182] Dhaene, K.; van Marck, E. \& Parwaresch, R. (2000). Telomeres, telomerase and cancer: an up-date. Virchows Arch 437: 1-16

[183] Taylor, R.; Ramirez, R.; Ogoshi, M.; Chaffins, M.; Piatyszek, M. \& Shay, J. (1996). Detection of telomerase activity in malignant and nonmalignant skin conditions. $J$ Invest Dermatol 106: 759-765

[184] Parris, C.; Jezzard, S.; Silver, A.; MacKie, R.; McGregor, J. \& Newbold, R. (1999). Telomerase activity in melanoma and non-melanoma skin cancer. Br J Cancer 79: 47-53

[185] Wu, A.; Ichihashi, M. \& Ueda, M. (1999). Correlation of the expression of human telomerase subunits with telomerase activity in normal skin and skin tumors. Cancer 86: 2038-2044 
[186] Kim, B.-C.; Ryoo, Y.-W. \&, Lee, K.-S. (2000). Telomerase activity in squamous cell carcinoma and basal cell carcinoma. Korean J Invest Dermatol 7: 184-187

[187] Chen, Z.; Smith, K.; Skelton, H.; Barrett, T.; Greenway, H.J. \&, Lo, S. (2001). Telomerase activity in Kaposi's sarcoma, squamous cell carcinoma, and basal cell carcinoma. Exp Biol Med (Maywood) 226: 753-757

[188] Boldrini, L.; Loggini, B.; Gisfredi, S.; Zucconi, Y.; Di Quirico, D.; Biondi, R.; Cervadoro, G.; Barachini, P.; Basolo, F.; Pingitore, R. \& Fontanini, G. (2003). Evaluation of telomerase in non-melanoma skin cancer. Int J Mol Med 11: 607-611

[189] Saleh, S.; King-Yin Lam, A.; Buettner, P.G.; Glasby, M.; Raasch, B. \& Ho, Y.H. (2007). Telomerase activity of basal cell carcinoma in patients living in North Queensland, Australia. Hum Pathol 38: 1023-1029

[190] Nakamura, T.M.; Morin, G.B.; Chapman, K.B. ; Weinrich, S.L.; Andrews,W.H.R.; Lingner, J.; Harley, C.B. \& Cech, T. (1997). Telomerase catalytic subunit homologs from fission yeast and human. Science 277: 955-959

[191] Harrington, L.; Zhou, W.; McPhail, T.; Oulton, R.; Yeung, D.; Mar, Y.; Bass, M. \& Robinson, M. (1997). Human telomerase contains evolutionarily conserved catalytic and structural subunits. Genes Dev 11:3109-3115

[192] Hu, S.; Chan, H.L.; Chen, M.C. \& Pang, J.H. (2002). Telomerase expression in benign and malignant skin neoplasms: comparison of three major subunits. J Formos Med Assoc 101: 593-597

[193] Ogoshi, M.; Le, T.; Shay, J. \& Taylor, R. (1998). In situ hybridization analysis of the expression of human telomerase RNA in normal and pathologic conditions of the skin. J Invest Dermatol 110: 818-823

[194] Attia, E.A.; Seada, L.S.; El-Sayed, M.H. \& El-Shiemy, S.M. (2010). Study of telomerase reverse transcriptase (hTERT) expression in normal, aged, and photo-aged skin. Int J Dermatol 49: 886-893

[195] Wu, Y.L.; Dudognon, C.; Nguyen, E.; Hillion, J.; Pendino, F.; Tarkanyi, I.; Aradi, J.; Lanotte, M.; Tong, J.H.; Chen, G.Q. \& Segal-Bendirdjian, E. (2006). Immunodetection of human telomerase reverse-transcriptase (hTERT) reappraised: nucleolin and telomerase cross paths. J Cell Sci 119: 2797-2806

[196] Kyo, S.; Masutomi, K.; Maida, Y.; Kanaya, T.; Yatabe, N.; Nakamura, M., Tanaka, M.; Takarada, M.; Sugawara, I.; Murakami, S.; Taira, T. \&, Inoue, M. (2003). Significance of immunological detection of human telomerase reverse transcriptase: reevaluation of expression and localization of human telomerase reverse transcriptase. Am J Pathol 163: 859-867

[197]Sun, P.M.; Wei, L.H.; Luo, M.Y.; Liu, G.; Wang, J.L.; Mustea, A.; Könsgen, D.; Lichtenegger, W. \& Sehouli, J. (2007). The telomerase activity and expression of hTERT gene can serve as indicators in the anti-cancer treatment of human ovarian cancer. Eur J Obstet Gynecol Reprod Biol 130: 149-157

[198] Ulrich, C.; Jürgensen, J.S.; Degen, A.; Hackethal, M.; Ulrich, M.; Patel, M.J.; Eberle, J.; Terhorst, D.; Sterry, W. \& Stockfleth, E. (2009). Prevention of non-melanoma skin cancer in organ transplant patients by regular use of a sunscreen: a 24 months, prospective, case-control study. Br J Dermatol 161 (Suppl. 3): 78-84

[199] Einspahr, J.G.; Bowden, G.T. \& Alberts, D.S. (2003). Skin cancer chemoprevention: strategies to save our skin. Recent Results Cancer Res 163: 151-164, discussion 264-266 
[200] Peck, G.L.; DiGiovanna, J.J.; Sarnoff, D.S.; Gross, E.G.; Butkus, D.; Olsen, T.G. \& Yoder, F.W. (1988). Treatment and prevention of basal cell carcinoma with oral isotretinoin. J Am Acad Dermatol 19: 176-185

[201] Greenberg, E.R.; Baron, J.A.;, Stukel, T.A.; Stevens, M.M.; Mandel, J.S.; Spencer, S.K.; Elias, P.M.; Lowe, N.; Nierenberg, D.W.; Bayrd, G.; Vance, J.C.; Freeman, D.H. Jr.; Clendenning, W.E.; Kwan, T. \& the Skin Cancer Prevention Study Group (1990). A clinical trial of beta carotene to prevent basal-cell and squamous-cell cancers of the skin. N Engl J Med 323: 789-795

[202] Tangrea, J.A.; Edwards, B.K.; Taylor, P.R.; Hartman, A.M.; Peck, G.L.; Salasche, S.J.; Menon, P.A.; Benson, P.M.; Mellette, J.R.; Guill, M.A.;Robinson, J.K.; Gui, J.D.; Stoll,H.L.; Grabski, W.J.; Winton, G.B. \& other members of the Isotretinoin-Basal Cell Carcinoma Study Group (1992). Long-term therapy with low-dose isotretinoin for prevention of basal cell carcinoma: a multicenter clinical trial. Isotretinoin-Basal Cell Carcinoma Study Group. J Natl Cancer Inst 84: 328-332

[203] Levine, N.; Moon, T.E.; Cartmel, B.; Bangert, J.L.; Rodney, S.; Dong, Q.; Peng, Y.M. \& Alberts, D.S. (1997). Trial of retinol and isotretinoin in skin cancer prevention: a randomized, double-blind, controlled trial. Southwest Skin Cancer Prevention Study Group. Cancer Epidemiol Biomarkers Prev 6: 957-961

[204] Tsao, A.S.; Kim, E.S. \& Hong, W.K. (2004). Chemoprevention of cancer. CA Cancer J Clin 54: $150-180$

[205] Otley, C.C.; Stasko, T.; Tope, W.D. \& Lebwo, M. (2006). Chemoprevention of nonmelanoma skin cancer with systemic retinoids: practical dosing and management of adverse effects. Dermatol Surg 32: 562-568

[206] Campbell, R.M. \& DiGiovanna, J.J. (2006). Skin cancer chemoprevention with systemic retinoids: an adjunct in the management of selected high-risk patients. Dermatol Ther 19: 306-314

[207] Clouser, M.C.; Roe, D.J.; Foote, J.A.; Harris, R.B. \& Alberts, D.S. (2010). Dose response of retinol and isotretinoin in the prevention of nonmelanoma skin cancer recurrence. Nutr Cancer 62: 1058-1066

[208] Lindelöf, B.; Sigurgeirsson, B.; Gäbel, H. \& Stern, R. (2000). Incidence of skin cancer in 5356 patients following organ transplantation. Br J Dermatol 143: 513-519

[209] Ulrich, C.; Schmook, T.; Sachse, M.M.; Sterry, W. \& Stockfleth, E. (2004). Comparative epidemiology and pathogenic factors for nonmelanoma skin cancer in organ transplant patients. Dermatol Surg 30: 622-627

[210] De Graaf, Y.G.; Euvrard, S. \& Bouwes Bavinck, J.N. (2004). Systemic and topical retinoids in the management of skin cancer in organ transplant recipients. Dermatol Surg 30: 656-661

[211] Lippman, S.M.; Heyman, R.A.; Kurie, J.M.; Benner, S.E. \& Hong, W.K. (1995): Retinoids and chemoprevention: clinical and basic studies. J Cell Biochem 22: 1-10

[212] Chandraratna, R.A. (1996). Tazarotene-first of a new generation of receptor-selective retinoids. Br J Dermatol 135: 18-25

[213] Kelloff, G.J. (2000). Perspectives on cancer chemoprevention research and drug development. Adv Cancer Res 78: 199-334

[214] Sun, S.Y. \& Lotan, R. (2002). Retinoids and their receptors in cancer development and chemoprevention. Crit Rev Oncol Hematol 41: 41-55 
[215] Dawson, M.I. \& Zhang, X.K. (2002). Discovery and design of retinoic acid receptor and retinoid $X$ receptor class- and subtype-selective synthetic analogs of all-transretinoic acid and 9-cis-retinoic acid. Curr Med Chem 9: 623-637

[216] Dawson, M.I. (2004). Synthetic retinoids and their nuclear receptors. Curr Med Chem Anticancer Agents 4: 199-230

[217] Bianchi, L.; Orlandi, A.; Campione, E.; Angeloni, C.; Costanzo, A.; Spagnoli, L.G. \& Chimenti, S. (2004). Topical treatment of basal cell carcinoma with tazarotene: a clinicopathological study on a large series of cases. Br J Dermatol 151: 148-156

[218] Mangelsdorf, D.J.; Ong, E.S.; Dyck, J.A. \& Evans, R.M. (1990). Nuclear receptor that identifies a novel retinoic acid response pathway. Nature 345: 224-228

[219] Heyman, R.A.; Mangelsdorf, D.J.; Dyck, J.A.; Stein, R.B.; Eichele, G.; Evans, R.M. \& Thaller, C. (1992). 9-cis retinoic acid is a high affinity ligand for the retinoid $X$ receptor. Cell 68: 397-406

[220] So, P.L.; Fujimoto, M.A. \& Epstein, E.H. Jr. (2008). Pharmacologic retinoid signaling and physiologic retinoic acid receptor signaling inhibit basal cell carcinoma tumorigenesis. Mol Cancer Ther 7: 1275-1284

[221] Einspahr, J.; Alberts, D.; Aickin, M.; Welch, K.; Bozzo, P.; Levine, N. \& Grogan, T. (1996). Evaluation of proliferating cell nuclear antigen as a surrogate end point biomarker in actinic keratosis and adjacent, normal-appearing, and non-sunexposed human skin samples. Cancer Epidemiol Biomarkers Prev 5: 343-348

[222] Einspahr, J.; Alberts, D.; Aickin, M.; Welch, K.; Bozzo, P.; Grogan, T. \& Nelson, M. (1997). Expression of p53 protein in actinic keratosis, adjacent, normal-appearing, and non-sun-exposed human skin. Cancer Epidemiol Biomarkers Prev 6: 583-587

[223] Kelloff, G.J.; Sigman, C.C.; Johnson, K.M.; Boone, C.W.; Greenwald, P.; Crowell, J.A.; Hawk, E.T. \& Doody, L.A. (2000). Perspectives on surrogate end points in the development of drugs that reduce the risk of cancer. Cancer Epidemiol Biomarkers Prev 9: 127-137

[224] Einspahr, J.G.; Stratton, S.P.; Bowden, G.T. \& Alberts, D.S. (2002). Chemoprevention of human skin cancer. Crit Rev Oncol Hematol 41: 269-285

[225] Orlandi, A.; Bianchi, L.; Costanzo, A.; Campione, E.; Spagnoli, L.G. \& Chimenti, S. (2004). Evidence of increased apoptosis and reduced proliferation in basal cell carcinomas treated with tazarotene. J Invest Dermatol 122: 1037-1041

[226] Kamradt, J. \& Reichrath, J. (1996). Expression of retinoic acid receptor proteins in basal cell carcinomas: an immunohistochemical analysis. J Histochem Cytochem 44: 14151420

[227] Hartmann, F.; Kosmidis, M.; Mühleisen, B.; French, L.E. \& Hofbauer, G.F. (2010). Retinoic acid receptor isoform mRNA expression differs between BCC and SCC of the skin. Arch Dermatol 146: 675-676

[228] Reichrath,J; Mittmann, M.; Kamradt, J. \& Müller, S.M. (1997). Expression of retinoid-X receptors (-alpha,-beta,-gamma) and retinoic acid receptors (-alpha,-beta,-gamma) in normal human skin: an immunohistological evaluation. Histochem J 29: 127-133

[229] Leung, K. (2007). ${ }^{124 I-A n t i-C D 44 v 6 ~ c h i m e r i c ~ m o n o c l o n a l ~ a n t i b o d y ~ U 36 . ~ M o l e c u l a r ~}$ Imaging and Contrast Agent Database (MICAD) [Internet] Bethesda (MD). National Center for Biotechnology Information (US): 1-3

[230] Leung, K. (2010). ${ }^{89}$ Zr-N-Succinyldesferal-anti-CD44v6 chimeric monoclonal antibody U36. Molecular Imaging and Contrast Agent Database (MICAD) [Internet] Bethesda (MD). National Center for Biotechnology Information (US): 1-3 


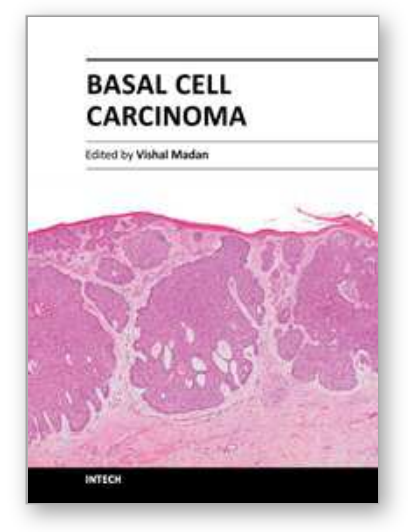

\author{
Basal Cell Carcinoma \\ Edited by Dr. Vishal Madan
}

ISBN 978-953-51-0309-7

Hard cover, 126 pages

Publisher InTech

Published online 14, March, 2012

Published in print edition March, 2012

Basal cell carcinoma is the commonest cutaneous malignancy. The last decade has witnessed exponential research which has broadened our understanding of the pathogenesis of basal cell carcinomas. This is also important from a therapeutic point of view as targeted approach to therapy is now being increasingly experimented. Although it is impossible to condense and present all good research in one book, the authors have to be commended on presenting their research on several aspects of basal cell carcinoma in a succinct manner, which shall not only enhance our understanding of, but also hopefully via this open exchange of ideas pave ways for successful targeted therapy of the commonest human cancer.

\title{
How to reference
}

In order to correctly reference this scholarly work, feel free to copy and paste the following:

Eva-Maria Fabricius, Bodo Hoffmeister and Jan-Dirk Raguse (2012). Molecularbiology of Basal Cell Carcinoma, Basal Cell Carcinoma, Dr. Vishal Madan (Ed.), ISBN: 978-953-51-0309-7, InTech, Available from: http://www.intechopen.com/books/basal-cell-carcinoma/molecularbiology-of-basal-cell-carcinoma

\section{INTECH}

open science | open minds

\section{InTech Europe}

University Campus STeP Ri

Slavka Krautzeka 83/A

51000 Rijeka, Croatia

Phone: +385 (51) 770447

Fax: +385 (51) 686166

www.intechopen.com

\section{InTech China}

Unit 405, Office Block, Hotel Equatorial Shanghai

No.65, Yan An Road (West), Shanghai, 200040, China

中国上海市延安西路65号上海国际贵都大饭店办公楼405单元

Phone: $+86-21-62489820$

Fax: +86-21-62489821 
(C) 2012 The Author(s). Licensee IntechOpen. This is an open access article distributed under the terms of the Creative Commons Attribution 3.0 License, which permits unrestricted use, distribution, and reproduction in any medium, provided the original work is properly cited. 